\title{
Chemical fractionation for the characterisation of fly ashes from co-combustion of biofuels using different methods for alkali reduction
}

\author{
Anita Pettersson ${ }^{\mathrm{a}, *}$, Lars-Erik Åmand ${ }^{\mathrm{b}}$, Britt-Marie Steenari ${ }^{\mathrm{c}}$ \\ ${ }^{a}$ University College of Borås, SE-50190 Borås, Sweden \\ ${ }^{\mathrm{b}}$ Department of Energy and Environment, Chalmers University of Technology, SE-412 96 Göteborg, Sweden \\ ${ }^{\mathrm{c}}$ Department of Chemical and Biological Engineering, Chalmers University of Technology, SE-412 96 Göteborg, Sweden
}

\section{A R T I C L E I N F O}

\section{Article history:}

Received 25 May 2008

Received in revised form 30 March 2009

Accepted 31 March 2009

Available online 18 April 2009

\section{Keywords:}

Alkali

Olivine

BFS

Zeolite

Fluidized bed

\begin{abstract}
A B S T R A C T
Chemical fractionation, SEM-EDX and XRD was used for characterisation of fly ashes from different cocombustion tests in a $12 \mathrm{MW}$ circulating fluidized bed boiler. The fuels combusted were wood pellets as base fuel and straw pellets as co-fuel in order to reach a fuel blend with high alkali and chlorine concentrations. This fuel blend causes severe problems with both agglomeration of bed material if silica sand is used and with deposits in the convection section of the boiler. Counter measures to handle this situation and avoiding expensive shut downs, tests with alternative bed materials and additives were performed. Three different bed materials were used; silica sand, Olivine sand and blast furnace slag (BFS) and different additives were introduced to the furnace of the boiler; Kaolin, Zeolites and Sulphur with silica sand as bed material. The results of the study are that BFS gives the lowest alkali load in the convection pass compared with Silica and Olivine sand. In addition less alkali and chlorine was found in the fly ashes in the BFS case. The Olivine sand however gave a higher alkali load in the convection section and the chemical fractionation showed that the main part of the alkali in the fly ashes was soluble, thus found as $\mathrm{KCl}$ which was confirmed by the SEM-EDX and XRD.

The comparison of the different additives gave that addition of Kaolin and Zeolites containing aluminium-silicates captured $80 \%$ of the alkali in the fly ash as insoluble alkali-aluminium-silikates and reduced the $\mathrm{KCl}$ load on the convection section. Addition of sulphur reduced the $\mathrm{KCl}$ load in the flue gas even more but the $\mathrm{K}_{2} \mathrm{SO}_{4}$ concentration was increased and $\mathrm{KCl}$ was found in the fly ashes anyhow. The chemical fractionation showed that $65 \%$ of the alkali in the fly ashes of the Sulphur case was soluble.
\end{abstract}

(c) 2009 Elsevier Ltd. All rights reserved.

\section{Introduction}

It is easy to start a fire, but to burn a fuel at optimal conditions regarding complete combustion, clean exhausts gases with respect to $\mathrm{NO}_{x}, \mathrm{SO}_{x}, \mathrm{HCl}, \mathrm{HF}$ and trace elements emissions as well as to achieve reliable operation conditions is altogether a challenge. New fuels and fuel blends are introduced with the aim to reduce the net contribution of $\mathrm{CO}_{2}$ to the atmosphere from combustion. Such fuels are agricultural wastes, municipal solid waste and municipal sewage sludge. Most of them have high concentrations of alkali metals ( $\mathrm{K}$ and $\mathrm{Na}$ ), chlorine and trace elements, combinations of which are known to cause combustion problems such as corrosion, deposit formation, slagging and bed agglomeration. These problems are not only dependent on high concentrations of alkali metals and chlorine in the fuel, but also linked to the availability or volatility of these elements during combustion. This gives

\footnotetext{
* Corresponding author. Tel.: +46 33 4355982; mobile: +46 70 7363182; fax: +46 334354008 .

E-mail address: anita.pettersson@hb.se (A. Pettersson).
}

entirely different conditions during combustion of biomass/waste than during combustion of coal where the alkali metal species are present in stable silicate forms.

Fluidised bed boilers are known to be very fuel flexible as well as having an even temperature distribution caused by the suspension firing of the fuel in a bed material that is fluidized. This makes FB boilers exceptionally suitable for co-combustion of solid fuels. However, these boilers are susceptible to bed agglomeration caused by chemical interaction of fuel ash components and the sand bed material forming new components with low melting points. In addition, an alkali chemistry is also present in the combustion chamber and convection section of the boiler leading to severe deposit problems if the conditions are unfavourable (high amounts of available alkali and chlorine). As a matter of fact, interdependence between the bed material chemistry and deposits problems can be expected since the trapping of alkali chlorides by a silica sand bed can decrease the deposit problems in the convection section of the boiler and vice versa.

Fuel characterisation by chemical fractionation has been suggested as a tool for determining whether the alkali content of 
the fuel is available for the alkali chemistry leading to deposit and agglomeration problems. In earlier work, a thorough fractionation investigation on several fuels was made [1]. For the reference fuel mix used in the present work (80\% wood pellets as base fuel and $20 \%$ straw pellets calculated on energy basis) the alkali was found to be available and alkali related problems during operation can thus be expected. In the present project, various strategies to avoid these problems were investigated and the work was focussed on studying if these measures resulted in different effects in different parts of the boiler. The first option tested was substitution of the normal silica sand bed material with two alternatives; olivine sand and blast furnace slag (BFS). Secondly, a number of additives were investigated: kaolin, elemental sulphur and zeolite (Doucil 24A) together with the reference bed material. The addition of zeolite to the combustion was made in order to study a sub-system of the ash chemistry taking place during co-combustion of bio fuel with sewage sludge $[1,2]$. The effect of the various strategies was investigated by thorough analysis of the fly ashes by chemical fractionation in order to reveal the mechanisms of the important alkali reactions.

The fractionation, which originally was developed for fuels, is based upon differences in solubility between different chemical forms of the elements studied. Thus, characteristic groups of compounds are dissolved and can be quantified. This methodology was first developed by Benson and Holm [3] for application on coals, used by Baxter et al. [4] and finally modified by ZevenhovenOnderwater [5] to be suitable for biofuels.

\section{Experimental}

\subsection{The fuels}

A fuel mixture of $80 \%$ wood pellets and $20 \%$ straw pellets calculated on energy basis was used in all combustion tests based on earlier experiences with this type of fuels in the boiler. The goal was to obtain a combustion situation with alkali and chlorine concentrations high enough to cause operational problems in the long

Table 1

Properties of the fuels studied in the project.

\begin{tabular}{|c|c|c|c|}
\hline & Straw & Wood pellets & Unit \\
\hline \multicolumn{4}{|c|}{ Proximate analysis } \\
\hline Water & 8.8 & 8.0 & wt\%, raw \\
\hline Ash & 5.6 & 0.3 & wt\%, dry \\
\hline Combustibles & 94.4 & 99.7 & wt\%, dry \\
\hline Volatiles & 81.0 & 95.2 & wt $\%$, daf \\
\hline \multicolumn{4}{|c|}{ Ultimate analysis } \\
\hline C & 49 & 51 & wt $\%$, daf \\
\hline $\mathrm{H}$ & 6.3 & 6.1 & wt $\%$, daf \\
\hline $\mathrm{O}$ & 43 & 43 & wt $\%$, daf \\
\hline $\mathrm{N}$ & 0.59 & $<0.01$ & wt\%, daf \\
\hline $\mathrm{S}$ & 0.10 & 0.06 & wt $\%$, daf \\
\hline $\mathrm{Cl}$ & 0.30 & $<0.01$ & wt\%, daf \\
\hline \multicolumn{4}{|l|}{ Heating value } \\
\hline HHV, daf & 18.4 & 18.9 & $\mathrm{MJ} \mathrm{kg}^{-} 1$ \\
\hline LHV, raw & 15.6 & 17.1 & $\mathrm{MJ} \mathrm{kg}^{-1}$ \\
\hline \multicolumn{4}{|l|}{ Ash analysis } \\
\hline K & 110 & 97 & $\mathrm{~g} \mathrm{~kg}^{-1}$ dry ash \\
\hline $\mathrm{Na}$ & 9.0 & 9.0 & $\mathrm{~g} \mathrm{~kg}^{-1}$ dry ash \\
\hline $\mathrm{Al}$ & 6.5 & 8.0 & $\mathrm{~g} \mathrm{~kg}^{-1}$ dry ash \\
\hline $\mathrm{Si}$ & 300 & 41 & $\mathrm{~g} \mathrm{~kg}^{-1}$ dry ash \\
\hline $\mathrm{Fe}$ & 2.1 & 8.4 & $\mathrm{~g} \mathrm{~kg}^{-1}$ dry ash \\
\hline $\mathrm{Ca}$ & 52 & 200 & $\mathrm{~g} \mathrm{~kg}^{-1}$ dry ash \\
\hline $\mathrm{Mg}$ & 10 & 34 & $\mathrm{~g} \mathrm{~kg}^{-1}$ dry ash \\
\hline$P$ & 14 & 12 & $\mathrm{~g} \mathrm{~kg}^{-1}$ dry ash \\
\hline $\mathrm{Ti}$ & 0.4 & 1.1 & $\mathrm{~g} \mathrm{~kg}^{-1}$ dry ash \\
\hline $\mathrm{Ba}$ & 0.4 & 3.7 & $\mathrm{~g} \mathrm{~kg}^{-1}$ dry ash \\
\hline
\end{tabular}

daf, dry and ash free, raw, as received. run, but not so high that it would be impossible to perform short time tests with a reasonable safety concerning the boiler operation. Table 1 presents the properties of the two fuels used in the study.

\subsection{The tests}

The 12-hour combustion tests were separated by a period of $36 \mathrm{~h}$ with wood pellet combustion and intensified regeneration of the bed. The aim was to secure that no memory effects from previous tests should interfere with the results obtained. Before the tests with alternative bed materials the boiler was operated for one week on a mixture of wood pellets and wood chips with a continuous replacement of bed material before the straw blending started.

\subsection{Bed materials}

The most common bed material used in fluidized bed combustors is silica sand consisting of $\mathrm{SiO}_{2}$ (quartz). The high quartz concentration often causes bed agglomeration in an alkali rich environment due to formation of alkali silicates with low melting points [6,7]. Previous works have shown that it is favourable to use bed materials that do not contain any quartz when burning alkali rich fuels or fuel blends [8]. In this study two such bed materials are compared to silica sand. The first one is Olivine sand which is a natural mineral consisting of $\mathrm{Mg}_{2} \mathrm{SiO}_{4}$ and $\mathrm{Fe}_{2} \mathrm{SiO}_{4}$, see Table 2. The other bed material is blast furnace slag (BFS) obtained as a by-product in iron and steel manufacturing. The slag is granulated and sieved into a suitable particle size fraction, yet containing a fine fraction. It is mainly amorphous and has a significant content of $\mathrm{Ca}$ and $\mathrm{Mg}$. Table 2 gives the chemical composition of the bed materials and additives used in the present work calculated as oxides.

\subsection{Additives}

The combustion cases where additives were tested were carried out with the same parameters as in the reference (Ref) case and with silica sand as bed material. The first additive was kaolin which is a white clay mineral consisting of kaolinite $\left(\mathrm{Al}_{2} \mathrm{O}_{3}\right.$. $2 \mathrm{SiO}_{2} \cdot 2 \mathrm{H}_{2} \mathrm{O}$ ). At temperatures of $450-600{ }^{\circ} \mathrm{C}$ kaolinite decomposes to amorphous meta-kaolinite. Kaolin has a large specific surface which adsorbs alkali compounds and thus inhibits the formation of vaporous alkali chlorides in combustion $[9,10]$. The suggested overall reaction for alkali metal chloride is shown below (R1). In the present work, the addition of kaolin was $40 \mathrm{~kg}$ per hour which corresponds to a kaolin to alkali $(\mathrm{K}+\mathrm{Na}$ in the fuel) molar ratio of 5 .

$$
\mathrm{Al}_{2} \mathrm{O}_{3} \cdot 2 \mathrm{SiO}_{2}(\mathrm{~s})+2 \mathrm{MCl}(\mathrm{g})+\mathrm{H}_{2} \mathrm{O}(\mathrm{g}) \rightarrow 2 \mathrm{MAlSiO}_{4}+2 \mathrm{HCl}(\mathrm{g})
$$

\section{Table 2}

Composition of bed materials and additives.

\begin{tabular}{lllllll}
\hline wt\% & $\begin{array}{l}\text { Silica } \\
\text { sand }\end{array}$ & $\begin{array}{l}\text { Olivine } \\
\text { sand }\end{array}$ & BFS & Kaolin & $\begin{array}{l}\text { Sulphur } \\
\text { granules }\end{array}$ & $\begin{array}{l}\text { Zeolite Douc. } \\
\text { A24 }\end{array}$ \\
\hline $\mathrm{SiO}_{2}$ & 98.9 & 42.05 & 34 & 46.6 & & $39.0-43.0$ \\
$\mathrm{CaO}$ & 0.123 & 0.08 & 32 & & & \\
$\mathrm{MgO}$ & 0.129 & 49.5 & 18 & & & $33.5-36.5$ \\
$\mathrm{Al}_{2} \mathrm{O}_{3}$ & 0.181 & 0.45 & 12 & 39.5 & & \\
$\mathrm{~K}_{2} \mathrm{O}$ & 0.06 & & 0.6 & & & 0.032 \\
$\mathrm{FeO}$ & ${ }^{*} 0.123$ & ${ }^{*} 7.05$ & 0.4 & & & \\
$\mathrm{MnO}$ & 0.013 & 0.075 & 0.7 & & 100 & $23.5-25.5$ \\
$\mathrm{~S}$ & & & 1.4 & & & \\
$\mathrm{Na}_{2} \mathrm{O}$ & 0.004 & & 0.6 & & & \\
\hline
\end{tabular}

$\mathrm{Fe}_{2} \mathrm{O}_{3}$. 
The second additive was a manufactured zeolite, Doucil 24A $\left(\mathrm{Na}_{2} \mathrm{O}\right)\left(\mathrm{Al}_{2} \mathrm{O}_{3}\right)\left(\mathrm{SiO}_{2}\right)_{2} \cdot 2,8 \mathrm{H}_{2} \mathrm{O}$, commonly used in household detergents. Zeolites are an important component in the new phosphate-free detergents as water softener and carrier of surfactants [11]. The zeolites most important task in the detergents is to capture the $\mathrm{Ca}$ and $\mathrm{Mg}$ ions in the washing water. The increasing use of phosphate-free detergents means an increased amount of zeolites will be captured in the waste water treatment plants in the future. The zeolites end up in the sewage sludge which in its turn may end up as a fuel for co-combustion in FB-boilers. The zeolites used here hade a density of $400-600 \mathrm{~g}\left(\mathrm{dm}^{3}\right)^{-1}(1250$ TAPS) and an average particle size of 1-5 microns. The zeolite Doucil 24A was introduced to the boiler in a flow giving the molar ratio Doucil $24 \mathrm{~A} / \mathrm{K}_{\mathrm{in}}$ with fuel of 1.1 .

The third additive was elemental sulphur in the form of granular with a coarseness of $1-5 \mathrm{~mm}$ (sulphur can be added in different forms as elemental sulphur as in the present tests but also as sulphate and various sulphates are available such as for example ammonium sulphate, iron sulphate or aluminium sulphate). Sulphur trioxide reacts with $\mathrm{KCl}$ and $\mathrm{NaCl}$ to form alkali sulphates according to the simplified Reaction (R2)

$2 \mathrm{MCl}(\mathrm{s})+\mathrm{SO}_{2}(\mathrm{~g})+1 / 2 \mathrm{O}_{2}(\mathrm{~g})+\mathrm{H}_{2} \mathrm{O} \rightarrow \mathrm{M}_{2} \mathrm{SO}_{4}(\mathrm{~s})+2 \mathrm{HCl}(\mathrm{g})$

where $\mathrm{M}$ is $\mathrm{K}$ or $\mathrm{Na}$.

A sufficient molar ratio for $\mathrm{S} / \mathrm{Cl}$ is necessary and this can vary from 0.5 to 4 depending on the form of sulphur used. There are also other factors related to the combustion that are of importance for an efficient sulphation of alkali chlorides [12]. Sulphation of $\mathrm{KCl}$ is both a gas phase reaction occurring in the furnace but also a gassolid reaction between solid $\mathrm{KCl}$ and gaseous sulphur oxides taking place in the convection section [13]. In the present investigation the addition of sulphur was $4 \mathrm{~kg}$ per hour which corresponds to a $\mathrm{S} / \mathrm{Cl}$ molar ratio of 6 in the combustion chamber.

\subsection{The research boiler}

The 12-MW $\mathrm{MW}_{\text {th }}$ circulating fluidized bed (CFB) boiler at Chalmers University of Technology (Göteborg, Sweden) was used for the combustion tests, Fig. 1

The combustion chamber (1) has a square cross-section of about $2.25 \mathrm{~m}^{2}$ and a height of $13.6 \mathrm{~m}$. The fuel (wood pellets + straw pellets) is fed to the bottom of the combustion chamber through a fuel chute (2). The Kaolin and Zeolites is supplied to the combustion from a separate bin (13) to the return leg where it is mixes with the hot particles coming from the primary cyclone (5) before it enters into the combustion chamber. Sulphur is fed at the same location but by different dosage equipment (14). Primary combustion air is supplied to the bottom of the combustion chamber (3), and secondary air is injected through a nozzle register located just above the fuel chute (4). After passing the exit duct of the cyclone (7), the flue gases are cooled to $150{ }^{\circ} \mathrm{C}$ in the convection section and the coarsest size fraction of the fly ashes are separated from the flue gases in a secondary cyclone (8) whereas the remaining fraction of fines is captured in a textile bag filter (9). This is not a common arrangement in commercial CFB boilers, but it has the advantage of giving fly ash samples with different size distributions depending on the collection point. This gives the opportunity to study how the particle size distribution influences the characteristics of the ash. The operating conditions are shown in Table 3.

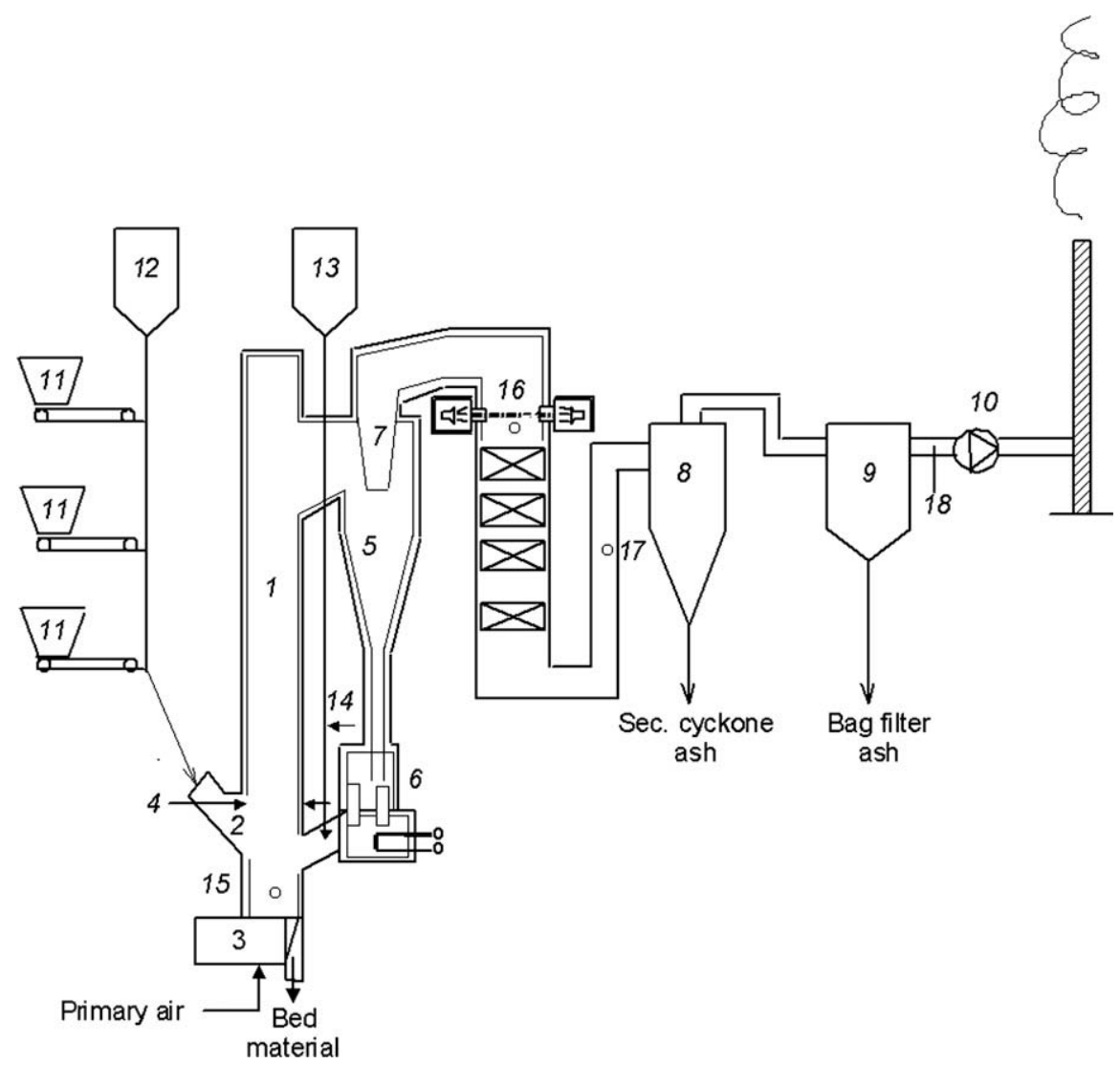

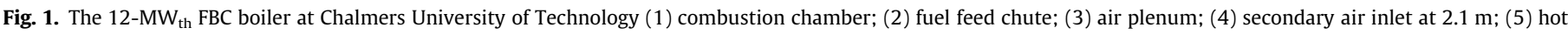

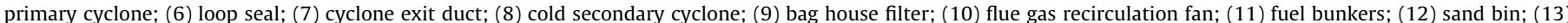

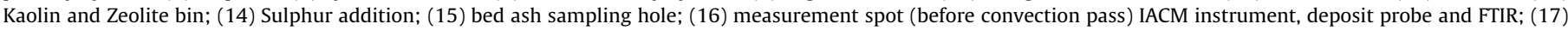
measurement spot (after convection pass) FTIR; (18) measurement spot (stack) FTIR. 
Table 3

Operating conditions

\begin{tabular}{llll}
\hline & Unit & Average & $\begin{array}{l}\text { Standard } \\
\text { deviation }\end{array}$ \\
\hline Load & $\mathrm{MW}_{\text {th }}$ & 6.2 & 0.24 \\
Fuel flow: wood pellets & $\mathrm{kg} \mathrm{DS} \mathrm{h}^{-1}$ & 1048 & 31 \\
Straw & $\mathrm{kg} \mathrm{DS} \mathrm{h}^{-1}$ & 276 & 4 \\
Share of straw & $\%$ on energy basis & 20 & 0.8 \\
Bed temp., (bottom) & ${ }^{\circ} \mathrm{C}$ & 851 & 2 \\
Bed temp., (top) & ${ }^{\circ} \mathrm{C}$ & 870 & 5 \\
Exit temp. after combustion chamber & ${ }^{\circ} \mathrm{C}$ & 822 & 10 \\
Exit temp. after bag filter & ${ }^{\circ} \mathrm{C}$ & 153 & 1 \\
Total riser pressure drop & $\mathrm{kPa}$ & 7.3 & 0.3 \\
$\begin{array}{l}\text { Excess air ratio } \\
\text { Primary air flow (total air flow) }\end{array}$ & $\%$ & 1.19 & 0.02 \\
Superficial flue gas velocity at top of & $\% \mathrm{~m} \mathrm{~s}^{-1}$ & 51 & 5 \\
riser $\mathrm{U}_{\text {top }}$ & & & \\
\hline
\end{tabular}

\subsection{Flue gas analysis}

The flue gases from the combustion were analysed by two sets of analysers and a FTIR (Fourier Transform Infra-Red spectrometry) is a vital part of one of these measuring loops. This FTIR can analyse $\mathrm{H}_{2} \mathrm{O}, \mathrm{CO}_{2}, \mathrm{SO}_{2}, \mathrm{NO}_{2}, \mathrm{CO}, \mathrm{NO}, \mathrm{HCl}, \mathrm{NH}_{3}$, $\mathrm{HF}$ and $\mathrm{N}_{2} \mathrm{O}$. On top of measuring conventional flue gas components alkali chlorides in gas phase were analysed as well by an IACM (In-situ Alkali Chloride Monitor) instrument [14]. This instrument continuously measures the sum of $\mathrm{KCl}$ and $\mathrm{NaCl}$ as well as $\mathrm{SO}_{2}$ in the flue gas and consists of one transmitter and one receiver placed on each sides of the super heater duct (No. 16 in Fig. 1). This location is determined by the fact that the alkali chlorides will condense to aerosols particles [15-17] if analysed downstream of the convection section. The detection limits on a transmitter-receiver distance of $5 \mathrm{~m}$ are approximately $1 \mathrm{ppm}$ for $\mathrm{KCl}$ and $\mathrm{NaCl}$ and $4 \mathrm{ppm}$ for $\mathrm{SO}_{2}$. The IACM gives the alkali loading of the flue gas prior to the convection section and the actual formation of alkali chlorides. This formation of alkali chlorides is dependent not only on the available alkali content of the fuels used (determined by chemical fractionation) but also on the presence of chlorine that in the present case originates from the straw but can be fed to the boiler by chlorine contaminated waste fractions in a co-firing mode with biofuels as base fuels.

\subsection{Chemical fractionation}

The chemical fractionation was carried out according to Zevenhoven-Onderwater [5]. It is a step by step leaching method (Fig. 2) resulting in selective extraction of inorganic elements, based on the solubility of their association forms in the fuels. The experimental procedure consists of three successive extractions. The first extraction is done by water only and is intended to both soak the fuel and remove the water soluble compounds such as alkaline salts. The second extraction with ammonium acetate dissolves ion exchangeable elements, such as sodium, calcium and magnesium, which are believed to be organically associated. Also part of $\mathrm{CaCO}_{3}$ may become dissolved. The third extraction step with hydrochloric acid removes acid soluble compounds such as carbonates and sulphates of other metals. The solid residue fraction consists of silicates, oxides, sulphides and other minerals [5]. After each step the solid sample is washed two times by deionised water. The washing water is added to the leachate prior to analysis.

The chemical fractionation method results in five samples for analysis: the original blended fly ash, three different leachates from the three fractionation steps and the solid residue remaining after the fractionation. For a more detailed explanation see Ref. [5].

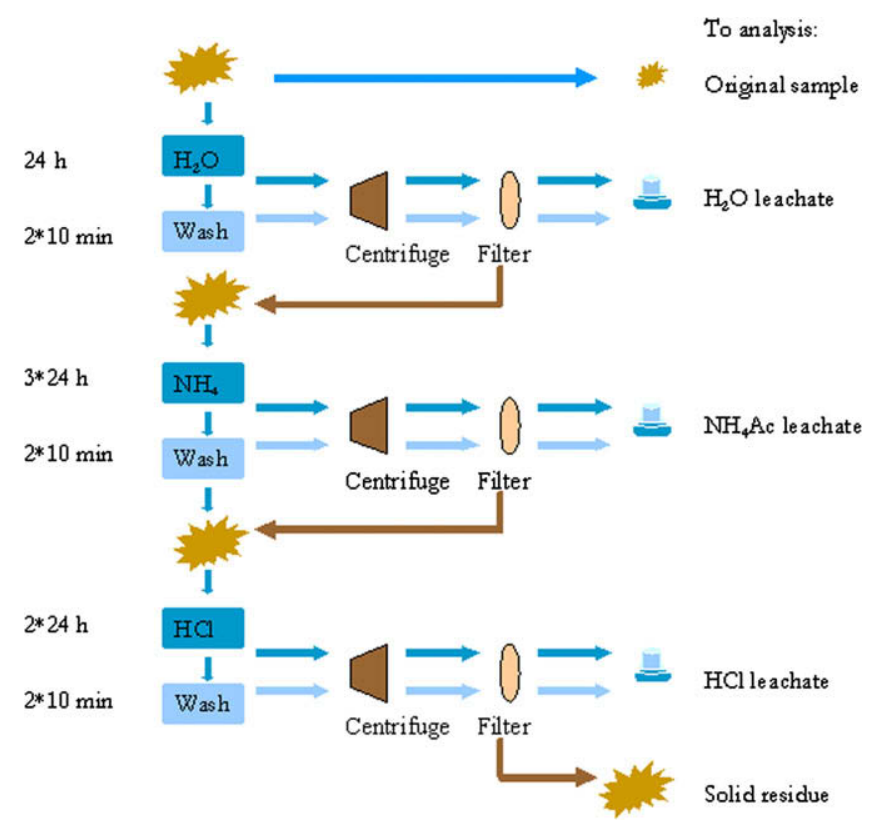

Fig. 2. Schematic view of the chemical fractionation procedure.

\subsection{Analytical methods}

Leachates and solid samples were analysed for $\mathrm{Ca}, \mathrm{Al}, \mathrm{Fe}, \mathrm{K}, \mathrm{Mg}$, $\mathrm{Na}, \mathrm{P}, \mathrm{Si}, \mathrm{S}, \mathrm{Cl}$ and Ti using Inductive Coupled Plasma with an Atomic Emission Spectroscopy detector (ICP-AES) or a Mass Spectrometer detector (ICP-MS). All solid samples were totally dissolved according to Swedish standards suitable for their individual characteristics before analysis; Sludge: SS028150-2, Coal: SS 187133 , Wood pellets, Straw and RDF: SS 187114/CEN/TS 14780, Ashes: SS 187117.

\subsection{Scanning electron microscopy and energy dispersive X-ray fluorescence spectrometry}

The topology of ash particles as well as of the solid residues remaining after chemical fractionation and filtration were examined by Scanning Electron Microscopy (SEM). In addition, the distribution of important elements in the sample structures was examined using Energy Dispersive X-ray Fluorescence spectrometry (EDX). The electron beam induces emission of element specific $\mathrm{X}$-ray wave lengths from the sample and by scanning the specimen surface with the detector element "maps" are obtained. In order to get information about elements quantities in the samples, semiquantitative point analyses were made.

In this work, both high-vacuum and low-vacuum (environmental SEM or ESEM) electron microscopes were used. The ESEM option gives the advantage that susceptible and non-conducting materials can be examined without damaging the sample material. The specimen is mounted by spreading on a carbon adhesive tape. No covering by a conducting material is needed. The charge build up on the sample surface is removed by a small injection of water vapour using the low vacuum mode in the microscope.

\subsection{X-ray powder diffractometry}

The main crystalline compounds in ash samples from the cocombustion tests were identified by qualitative X-ray powder diffractometry (XRD) using a Siemens D5000 X-ray powder diffractometer with the characteristic $\mathrm{Cu}$ radiation and a scintillation detector. The identification of compounds was performed through 
comparison with standards in the Joint Committee of Powder Diffraction Standards [18].

\section{Results and discussion}

\subsection{Flue gas composition}

Fig. 3 shows concentrations of gaseous alkali chlorides, $\mathrm{HCl}$ and $\mathrm{SO}_{2}$ in the flue gas at the same location as where the deposit probe was inserted (16 in Fig. 1). The only test case that gave a higher concentration of $\mathrm{KCl}(\mathrm{g})$ in the flue gas than the Ref case was the Olivine bed material test. The high $\mathrm{KCl}$ concentrations in the Olivine case was shown to cause alkali rich deposits on heat transfer surfaces in the boiler [19]. The use of BFS as bed material lowered the flue gas $\mathrm{KCl}$ content somewhat relative to the Ref case but not significantly, neither did the addition of kaolin or zeolites. However, when sulphur was added the content decreased to $10 \mathrm{ppm}$ from the Ref case level of $28 \mathrm{ppm}$.

The variation in flue gas $\mathrm{HCl}$ concentration between the different test cases was smaller than that of the $\mathrm{KCl}$ concentration. However, a tendency towards higher concentrations of $\mathrm{HCl}$ in the cases where Kaolin and Zeolites were added than in the Ref case can be seen. This coincides with a decrease in concentration of gaseous $\mathrm{KCl}$. Hence the Kaolin and Zeolite cases suppressed the $\mathrm{KCl}$ in favour of $\mathrm{HCl}$.
The sulphur addition resulted in a significant increase in $\mathrm{SO}_{2}$ concentration relative to the Ref case, whereas the other cases showed only minor variations. The low $\mathrm{KCl}$ and high $\mathrm{SO}_{2}$ concentration in the flue gas from the Sulphur case indicates that the sulphation was efficient.

\subsection{Ash composition and element distribution}

The element contents in the secondary cyclone, bag filter and bed ashes are shown in Table 4. Over all, the alkali concentrations in the bed ashes did not differentiate much, but the Zeolite case had the highest alkali concentrations in all ash fractions which mostly derive from the $\mathrm{Na}$ in the added zeolites. The Olivine case had the lowest alkali concentrations. The influence of the different bed materials on the general bed material chemistry is clearly seen on the ash composition with decreased Si and increased $\mathrm{Mg}$ concentrations in the Olivine and BFS cases. The influence of the additives is clearly seen as well with elevated $\mathrm{Al}$ concentrations in the Kaolin and Zeolite cases and increased S in the Sulphur case. The different tests gave different ash flows as shown in the ash balances in Table 5 . The reason for this was partly a deliberate variation in bed regeneration (increased in and outflow of bed material) in order to avoid a shut down of the boiler during the long time tests of the various bed materials. In the Zeolite case no new bed material was added during the combustion test, thus a very low

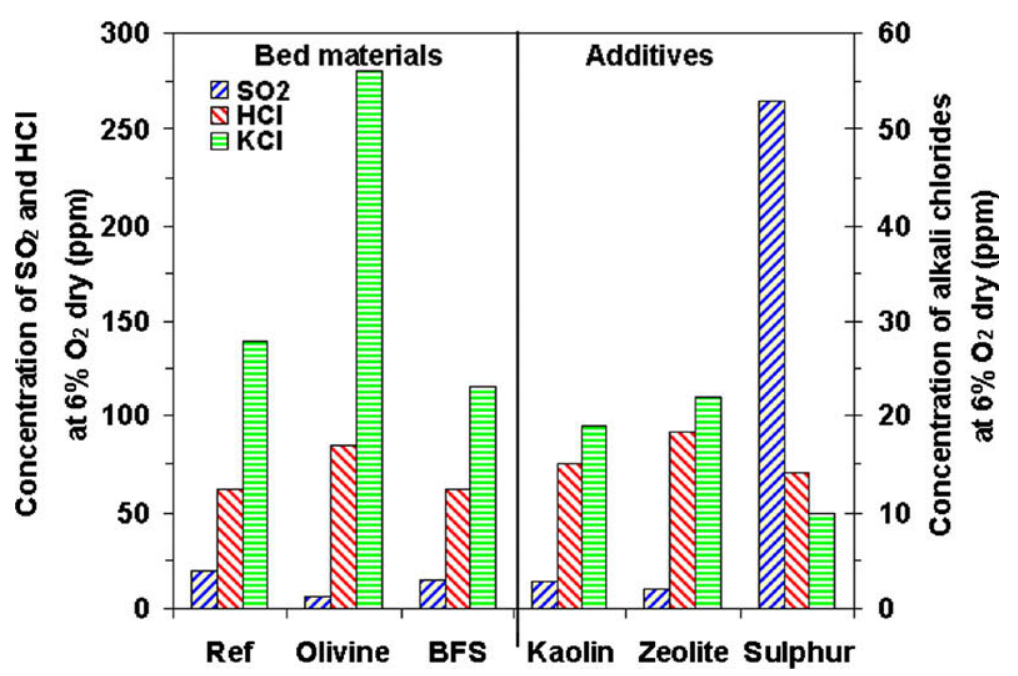

Fig. 3. Flue gas concentrations of gaseous $\mathrm{HCl}, \mathrm{SO}_{2}$ and alkali chlorides measured before the convection pass. The scales are different for $\mathrm{HCl}, \mathrm{SO} \mathrm{O}_{2}$ and alkali chlorides.

Table 4

Concentration of main elements in ash samples from the Ash combustion tests.

\begin{tabular}{|c|c|c|c|c|c|c|c|c|c|c|c|c|c|c|c|c|c|c|}
\hline \multicolumn{19}{|c|}{ Analysis; main elements ( $\mathrm{g} \mathrm{kg}^{-1}$ dry ash) } \\
\hline & \multicolumn{3}{|l|}{ Ref } & \multicolumn{3}{|c|}{ Olivine } & \multicolumn{3}{|l|}{ BFS } & \multicolumn{3}{|c|}{ Kaolin } & \multicolumn{3}{|c|}{ Zeolite } & \multicolumn{3}{|c|}{ Sulphur } \\
\hline & Bed & Sec. сус & Bag fil. & Bed & Sec. сус & Bag fil. & Bed & Sec. сус & Bag fil. & Bed & Sec. сус & Bag fil. & Bed & Sec. сус & Bag fil. & Bed & Sec. сус & Bag fil. \\
\hline K & 13 & 53 & 90 & 8.3 & 43 & 77 & 12 & 17 & 53 & 11 & 60 & 96 & 15 & 61 & 91 & 14 & 51 & 63 \\
\hline $\mathrm{Na}$ & 1.0 & 5.4 & 6.2 & 0.6 & 5.6 & 4.2 & 3.6 & 4.3 & 3.9 & 0.4 & 2.4 & 3.2 & 13 & 22 & 90 & 0.9 & 3.8 & 5.6 \\
\hline $\mathrm{Al}$ & 2.4 & 21 & 11 & 1.1 & 43 & 9.0 & 62 & 51 & 45 & 15 & 93 & 110 & 13 & 46 & 119 & 3.5 & 15 & 18 \\
\hline $\mathrm{Si}$ & 490 & 267 & 96 & 190 & 172 & 77 & 170 & 157 & 127 & 480 & 240 & 169 & 420 & 265 & 159 & 440 & 323 & 107 \\
\hline $\mathrm{Fe}$ & 4.7 & 27 & 20 & 46 & 63 & 23 & 7.0 & 2.9 & 9.8 & 7.0 & 8.5 & 8.7 & 3.3 & 10 & 2.4 & 4.6 & 10 & 12 \\
\hline $\mathrm{Ca}$ & 16 & 79 & 157 & 11 & 94 & 129 & 220 & 186 & 205 & 13 & 72 & 110 & 12 & 60 & 31 & 16 & 51 & 146 \\
\hline $\mathrm{Mg}$ & 3.0 & 12 & 31 & 280 & 92 & 99 & 100 & 82 & 67 & 31 & 13 & 18 & 2.4 & 8.0 & 3.0 & 6.7 & 14 & 26 \\
\hline$P$ & 1.1 & 16 & 20 & 1.0 & 17 & 11 & 0.6 & 1.4 & 4.7 & 0.6 & 3.2 & 9.0 & 1.4 & 7.8 & 3.1 & 1.1 & 6.9 & 13 \\
\hline $\mathrm{Ti}$ & 0.7 & 1.6 & 1.6 & 0.07 & 2.6 & 0.5 & 12 & 9.8 & 7.4 & 0.0 & 0.4 & 0.3 & 0.6 & 1.0 & 0.2 & 0.8 & 1.0 & 0.8 \\
\hline$S$ & 0.4 & 6.4 & 0.5 & 0.2 & 6.4 & 28 & 8.4 & 8.9 & 29 & 0.4 & 2.7 & 8.4 & 0.2 & 8.8 & 8.8 & 0.2 & 6.2 & 75 \\
\hline $\mathrm{Cl}$ & $<0.1$ & 4.0 & 68 & $<0.1$ & 0.0 & 98 & 0.2 & 0.9 & 32 & $<0.1$ & 2.1 & 24 & $<0.1$ & 2.0 & 24 & $<0.1$ & 2.2 & 32 \\
\hline
\end{tabular}


Table 5

Ash flows $\left[\mathrm{kg} \mathrm{h}^{-1}\right]$ and ash balance.

\begin{tabular}{lccrrrr}
\hline & Sec. cyc & Bag filter & Bed & Ash out & Ash in & Out/in $* 100(\%)$ \\
\hline Ref & 9.9 & 1.9 & 92.3 & 104.1 & 106.2 & 98 \\
Olivine & 6.3 & 2.9 & 87.0 & 96.3 & 95.2 & 101 \\
BFS & 61.3 & 5.7 & 63.6 & 130.6 & 167.7 & 78 \\
Kaolin & 23.8 & 14.0 & 23.5 & 61.3 & 77.3 & 79 \\
Zeolite & 5.9 & 13.1 & 1.5 & 20.5 & 25.7 & 80 \\
Sulphur & 9.7 & 2.0 & 86.6 & 98.3 & 84.9 & 116 \\
\hline
\end{tabular}

bed ash flow was monitored for this test. For the other tests (Ref, Olivine, BFS, Kaolin and Sulphur cases) this means that the elements from the fuel ashes are much more diluted by fresh bed material. This will have the greatest impact on the bed sample but also on the fly ashes since part of the bed material end up as fly ash due to attrition of the bed material. The high secondary cyclone ash flow in the BFS case is due to the raw BFS having a large fraction of very small particles that follows the flue gas immediately when introduced to the boiler. To achieve a relevant pressure drop over the bed it was necessary to increase the bed material feeding significantly. The closure of the ash balances over the tests was good considering the size of the boiler.

The element balances over the boiler are shown in Table 6. The results varied for the different combustion tests and especially the Zeolite case had a lower outflow than inflow of several elements suggesting an accumulation of these elements in the boiler. This was also stated by the deposit probe measurements [20] where this test gave the largest deposit formation in the convection section. The deposits contained $\mathrm{Si}, \mathrm{Al}, \mathrm{Na}$ and $\mathrm{K}$, very much reflecting the composition of the original zeolites with the exception of $\mathrm{K}$. This indicates that the zeolites have captured $\mathrm{K}$ from the gas phase. Anyhow, all these combustion tests generated more or less depos-

Table 6

Element balances over the boiler and element distribution in the ashes for the various combustion cases.

\begin{tabular}{|c|c|c|c|c|c|c|}
\hline Case wt\% & Ref & Olivine & BFS & Kaolin & Zeolite & Sulphur \\
\hline $\mathrm{K}_{\text {out }} \mathrm{K}_{\text {in }}^{-1}$ & 76.4 & 48.4 & 79.3 & 125.1 & 40.7 & 76.4 \\
\hline $\mathrm{Na}_{\text {out }} \mathrm{Na}_{\text {in }}^{-1}$ & 191.0 & 117.0 & 86.0 & 142.6 & 26.0 & 169.0 \\
\hline $\mathrm{Ca}_{\text {out }} \mathrm{Ca}_{\text {in }}^{-1}$ & 143.0 & 104.0 & 96.8 & 199.9 & 35.6 & 132.9 \\
\hline $\mathrm{Al}_{\text {out }} \mathrm{Al}_{\text {in }}^{-1}$ & 1015 & 755.8 & 102.8 & 52.3 & 30.6 & 1076.6 \\
\hline $\mathrm{S}_{\text {out }} \mathrm{S}_{\text {in }}^{-1}$ & 88.9 & 62.6 & 74.3 & 103.4 & 90.2 & 83.2 \\
\hline $\mathrm{Cl}_{\text {out }} \mathrm{Cl}_{\text {in }}^{-1}$ & 71.3 & 78.4 & 88.6 & 139.9 & 70.9 & 105.1 \\
\hline \multicolumn{7}{|c|}{ Sec. cyclone (wt\% of tot out) } \\
\hline K & 28.3 & 23.2 & 40.8 & 44.2 & 22.7 & 31.2 \\
\hline $\mathrm{Na}$ & 34.6 & 37.8 & 41.2 & 47.5 & 9.7 & 34.1 \\
\hline $\mathrm{Ca}$ & 31.1 & 31.9 & 33.3 & 45.1 & 43.5 & 26.2 \\
\hline $\mathrm{Al}$ & 46.8 & 70.1 & 32.6 & 50.5 & 14.6 & 34.6 \\
\hline $\mathrm{S}$ & 23.0 & 21.1 & 31.0 & 18.6 & 15.4 & 1.9 \\
\hline $\mathrm{Cl}$ & 8.2 & 0.1 & 8.7 & 4.9 & 1.5 & 3.1 \\
\hline \multicolumn{7}{|c|}{ Bag filter (wt\% of tot out) } \\
\hline K & 9.0 & 18.7 & 12.0 & 41.8 & 71.3 & 7.8 \\
\hline $\mathrm{Na}$ & 7.4 & 12.7 & 3.5 & 37.4 & 84.1 & 10.4 \\
\hline $\mathrm{Ca}$ & 11.6 & 19.6 & 3.4 & 40.7 & 47.2 & 15.1 \\
\hline $\mathrm{Al}$ & 4.5 & 6.6 & 2.7 & 35.3 & 80.9 & 8.1 \\
\hline $\mathrm{S}$ & 0.3 & 41.0 & 9.5 & 34.2 & 32.2 & 4.5 \\
\hline $\mathrm{Cl}$ & 26.1 & 53.3 & 29.8 & 33.3 & 38.4 & 9.1 \\
\hline \multicolumn{7}{|c|}{ Bottom bed (wt\% of tot out) } \\
\hline K & 62.7 & 58.1 & 47.2 & 14.1 & 6.0 & 61.1 \\
\hline $\mathrm{Na}$ & 58.0 & 49.5 & 55.3 & 15.1 & 6.2 & 55.5 \\
\hline $\mathrm{Ca}$ & 57.3 & 48.5 & 63.3 & 14.2 & 9.3 & 58.7 \\
\hline $\mathrm{Al}$ & 48.7 & 23.3 & 64.8 & 14.2 & 4.5 & 57.3 \\
\hline $\mathrm{S}$ & 13.1 & 8.1 & 46.9 & 4.7 & 0.4 & 0.5 \\
\hline $\mathrm{Cl}$ & 1.9 & 1.6 & 1.6 & 0.4 & 0.1 & 1.0 \\
\hline \multicolumn{7}{|c|}{ Fluegas (wt\% of tot out) } \\
\hline $\mathrm{S}$ & 63.5 & 29.7 & 12.6 & 42.6 & 51.9 & 93.1 \\
\hline $\mathrm{Cl}$ & 63.8 & 45.0 & 59.9 & 61.4 & 60.1 & 86.8 \\
\hline
\end{tabular}

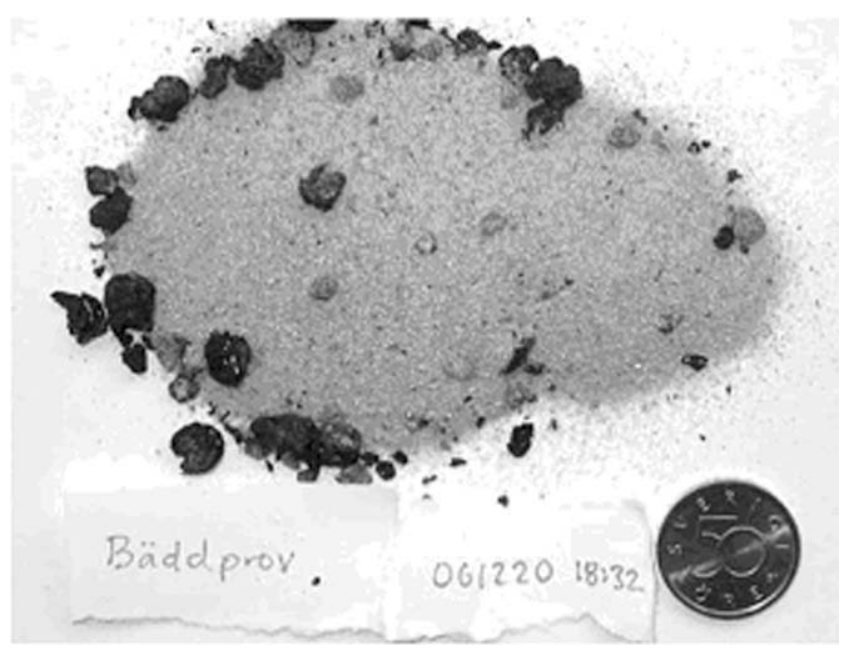

Fig. 4. Picture of "straw stones" sintered ash particles in the bed ash from the Ref case.

its [19]. The large outflow of $\mathrm{Al}$ in the three cases, Ref, Olivine and Sulphur may have been caused by memory effects from previous combustion tests having a high $\mathrm{Al}$ concentration or it may be due to uncertainty in the results since the molar flow of $\mathrm{Al}$ in these tests is low.

In the Kaolin case the largest alkali flow was found in the secondary cyclone ash, whereas in the Ref, Olivine, BFS and Sulphur cases the main part of the alkali was found in the bed ash, Table 6 . These cases were also run with the highest bed regeneration. In the bed material drain "straw stones" (sintered straw ash, see Fig. 4) could be identified. These agglomerates were probably causing the high alkali flows. For the Kaolin and Zeolite cases with their low bed removal flows these "straw stones" were instead eroded in the bed leading to the production of fines entrained as fly ash. The Zeolite case was the only case were the largest alkali flow was found in the bag filter ash and the molar ratio of alkali to chlorine was 9 compared to $0.8-3.8$ in the bag filter ash in the other cases. In addition, the $\mathrm{Al}$ and $\mathrm{Si}$ concentrations were very high (Table 4) compared to the $\mathrm{Cl}$ indicating a capture of alkali as alkali-Al-Si in the ash. The Zeolite case also had the highest bag filter ash flow of all the combustion tests with $13.1 \mathrm{~kg} \mathrm{~h}^{-1}$ compared to $1.9 \mathrm{~kg} \mathrm{~h}^{-1}$ in the case with the lowest flow, the Ref case, Table 5. The Kaolin case showed similar tendencies, but most alkali-Al-Si was found in the sec. cyclone ash, thus indicating the presence of alkali silicates in larger particles. In all cases more than $50 \%$ of the $\mathrm{Cl}$ was found in the flue gas except for the Olivine case were most $\mathrm{Cl}$ ended up in the bag filter ash, Table 6. In the Sulphur case having the highest S flow as much as $93.1 \%$ was leaving the boiler with the flue gas. However, the $S$ concentrations in the bag filter ash from this case had the highest $\mathrm{S}$ concentrations of all the cases any way, Table 4 . In the Kaolin and Zeolite cases approximately 50\% of the $\mathrm{S}$ leaved with the flue gas and the rest was distributed over the two fly ash fractions.

\section{3. $X R D$ analysis}

XRD was used to investigate the mineralogy of ash samples from the combustion tests. It should be noted that the detection limit of a crystalline compounds by XRD is about $2 \%$ by weight and that the composition of amorphous phases cannot be identified.

The largest difference among the ashes derived from different bed materials (Table 7) was the presence of Mg compounds and calcium-aluminium-silicates in the Olivine BFS cases. $\mathrm{KCl}$ was 
Table 7

Results of the XRD analysis on the three cases with different bed material.

\begin{tabular}{|c|c|c|c|c|c|c|}
\hline & \multicolumn{2}{|l|}{ Ref } & \multicolumn{2}{|l|}{ Olivine } & \multicolumn{2}{|l|}{ BFS } \\
\hline & $\begin{array}{l}\text { Sec. } \\
\text { cyclone }\end{array}$ & $\begin{array}{l}\text { Bag } \\
\text { filter }\end{array}$ & $\begin{array}{l}\text { Sec. } \\
\text { cyclone }\end{array}$ & $\begin{array}{l}\text { Bag } \\
\text { filter }\end{array}$ & $\begin{array}{l}\text { Sec. } \\
\text { cyclone }\end{array}$ & $\begin{array}{l}\text { Bag } \\
\text { filter }\end{array}$ \\
\hline $\mathrm{KCl}$ & Trace & Major & Trace & Major & & Major \\
\hline $\mathrm{K}_{3} \mathrm{Na}\left(\mathrm{SO}_{4}\right)_{2}$ & & & Trace & Minor & & \\
\hline $\mathrm{CaCO}_{3}$ & Minor & Minor & Major & Minor & & \\
\hline $\mathrm{CaSO}_{4}$ & & Minor & & & & Minor \\
\hline $\mathrm{SiO}_{2}$ & Major & Minor & Major & & Minor & Minor \\
\hline $\mathrm{KAISi}_{3} \mathrm{O}_{8}$ & Minor & & Minor & & & \\
\hline $\mathrm{K}_{4} \mathrm{CaSi}_{3} \mathrm{O}_{9}$ & & Minor & & & & \\
\hline $\mathrm{K}_{2} \mathrm{Al}_{19} \mathrm{O}_{29.5}$ & & Minor & & & & \\
\hline $\mathrm{K}_{2} \mathrm{MgSiO}_{4}$ & & & & Minor & & \\
\hline $\mathrm{CaSi}_{2} \mathrm{O}_{5}$ & Minor & Trace & & & & \\
\hline $\mathrm{CaAl}_{2} \mathrm{Si}_{2} \mathrm{O}_{8}$ & & & Trace & & & \\
\hline $\mathrm{Ca}_{2} \mathrm{Al}_{2} \mathrm{SiO}_{7}$ Gehlenite $^{\mathrm{a}}$ & & & Trace & Trace & Major & Major \\
\hline $\mathrm{Ca}_{2} \mathrm{MgSi}_{2} \mathrm{O}_{7}$ Akermanite $^{\mathrm{a}}$ & & & & & Major & Major \\
\hline $\mathrm{Ca}_{3} \mathrm{Mg}\left(\mathrm{SiO}_{4}\right)_{2}$ & & & & Trace & & \\
\hline $\mathrm{CaMgSiO}_{4}$ & & & & & & Minor \\
\hline $\mathrm{CaFeSiO}_{4}$ & & & & & & Minor \\
\hline $\mathrm{MgO}$ & & & & Minor & & Minor \\
\hline $\mathrm{Mg}_{2} \mathrm{SiO}_{4}$ forsterite & & & Minor & Minor & & \\
\hline$(\mathrm{Mg}, \mathrm{Fe})_{2} \mathrm{SiO}_{4}$ forsterite & & & & Minor & & \\
\hline
\end{tabular}

a Gehlenite and Akermanite are very similar in structure, and the specie found here is probably a mixture or a solid solution of these.

found in all ashes except the sec. cyclone ash in the BFS case which also contained the fewest crystalline compounds.

In the Kaolin and Sulphur cases $\mathrm{KCl}$ was found in all fly ashes especially the bag filter ashes (Table 8). Compounds containing sulphur, such as $\mathrm{K}_{2} \mathrm{SO}_{4}$ or $\mathrm{CaSO}_{4}$, together with $\mathrm{KCl}$ and $\mathrm{KAlSi}_{3} \mathrm{O}_{8}$ dominated the ashes from the Sulphur case. The Kaolin and Zeolite cases were dominated by different aluminium-silicates as $\mathrm{Ca}_{2} \mathrm{Al}_{2-}$ $\mathrm{SiO}_{7}$, Nepheline and $\mathrm{KAlSi}_{3} \mathrm{O}_{8}$.

\subsection{Fractionations of fly ashes derived from different bed materials}

The results in Fig. 5 are the average results from the ash total element concentration analyses and from the fractionation analyses. The ash samples used in the chemical fractionation were mixtures of fly ash from the secondary cyclone and from the bag filter weighted according to the measured ash flows in the combustion tests. In the Ref and BFS cases the results from the ash analysis
Table 8

Results of the XRD analysis on the three cases with different additives.

\begin{tabular}{|c|c|c|c|c|c|c|}
\hline & \multicolumn{2}{|l|}{ Kaoline } & \multicolumn{2}{|l|}{ Zeolite } & \multicolumn{2}{|l|}{ Sulphur } \\
\hline & $\begin{array}{l}\text { Sec. } \\
\text { cyclone }\end{array}$ & $\begin{array}{l}\text { Bag } \\
\text { filter }\end{array}$ & $\begin{array}{l}\text { Bag } \\
\text { filter }\end{array}$ & $\begin{array}{l}\text { Bag } \\
\text { filter }\end{array}$ & $\begin{array}{l}\text { Sec. } \\
\text { cyclone }\end{array}$ & $\begin{array}{l}\text { Bag } \\
\text { filter }\end{array}$ \\
\hline $\mathrm{KCl}$ & Trace & Major & & & Trace & Major \\
\hline $\mathrm{CaKCl}_{3}$ & Trace & & & & & \\
\hline $\mathrm{K}_{2} \mathrm{SO}_{4}$ & & & & & Trace & Minor \\
\hline $\mathrm{K}_{3} \mathrm{Na}\left(\mathrm{SO}_{4}\right)_{2}$ & & & & & & Minor \\
\hline $\mathrm{K}_{2} \mathrm{CO}_{3}$ & & & & & & Minor \\
\hline $\mathrm{CaO}$ & Trace & & & & & Trace \\
\hline $\mathrm{CaCO}_{3}$ & Minor & & Minor & & Trace & Trace \\
\hline $\mathrm{CaSO}_{4}$ & Minor & Minor & & & Trace & Minor \\
\hline $\mathrm{KAISi}_{3} \mathrm{O}_{8}$ & Trace & & Minor-trace & & Minor & Trace \\
\hline $\mathrm{KAISi}_{3} \mathrm{O}_{8}$ Sanidine & Trace & & & Trace $^{a}$ & & \\
\hline $\mathrm{K}_{4} \mathrm{CaSi}_{3} \mathrm{O}_{9}$ & & & & Minor & & \\
\hline $\mathrm{KAlSiO}_{4}$ & & & & Minor & & \\
\hline $\mathrm{KAl}_{3} \mathrm{Si}_{3} \mathrm{O}_{11}$ & Minor & & & & & \\
\hline $\mathrm{K}(\mathrm{Na}, \mathrm{K})_{3} \mathrm{Al}_{4} \mathrm{Si}_{4} \mathrm{O}_{16}$ & & & Minor-trace & Trace & & \\
\hline $\mathrm{NaAlSiO}_{4}$ Nepheline & & & & Major & & \\
\hline $\mathrm{SiO}_{2}$ Quartz & Major & Major & Major & & Major & \\
\hline $\mathrm{SiO}_{2}$ Cristobalite & & & Minor & & Minor & \\
\hline $\mathrm{Ca}_{2} \mathrm{SiO}_{4}$ & Minor & & & & & \\
\hline $\mathrm{Ca}_{2} \mathrm{Al}_{2} \mathrm{SiO}_{7}$ & Minor & Minor & & & & \\
\hline $\mathrm{CaAl}_{2} \mathrm{Si}_{2} \mathrm{O}_{8}$ & Minor & & & & & \\
\hline
\end{tabular}

a Na-substituted

and the fractionation analysis agreed very well, whereas in the Olivine case there were disparities between some of the results, especially for $\mathrm{Ca}, \mathrm{Mg}$, Si, Fe and $\mathrm{K}$ as shown in Fig. 5. Both analyses were carried out several times and the differences remained. The reason for this disparity is unclear.

The olivine bed material did not contribute to a more stable chemical binding of the potassium than the quartz sand did in the reference case (Fig. 5). In fact, the potassium was more soluble in the Olivine case and this indicates that the alkali to a large extent remains in the straw ash agglomerates, the "straw stones". Calcium, sodium, chlorine and sulphur were also bound in compounds with similar solubility in the Ref and Olivine samples. The Olivine itself contributed with some Fe and $\mathrm{Mg}$, but these elements are both present in stable forms and are not expected to cause ash deposits. The results further showed a larger amount of $\mathrm{Al}$ soluble in ammonium acetate solution in the fly ash formed in the Olivine case (35\%) than in the corresponding ash from the

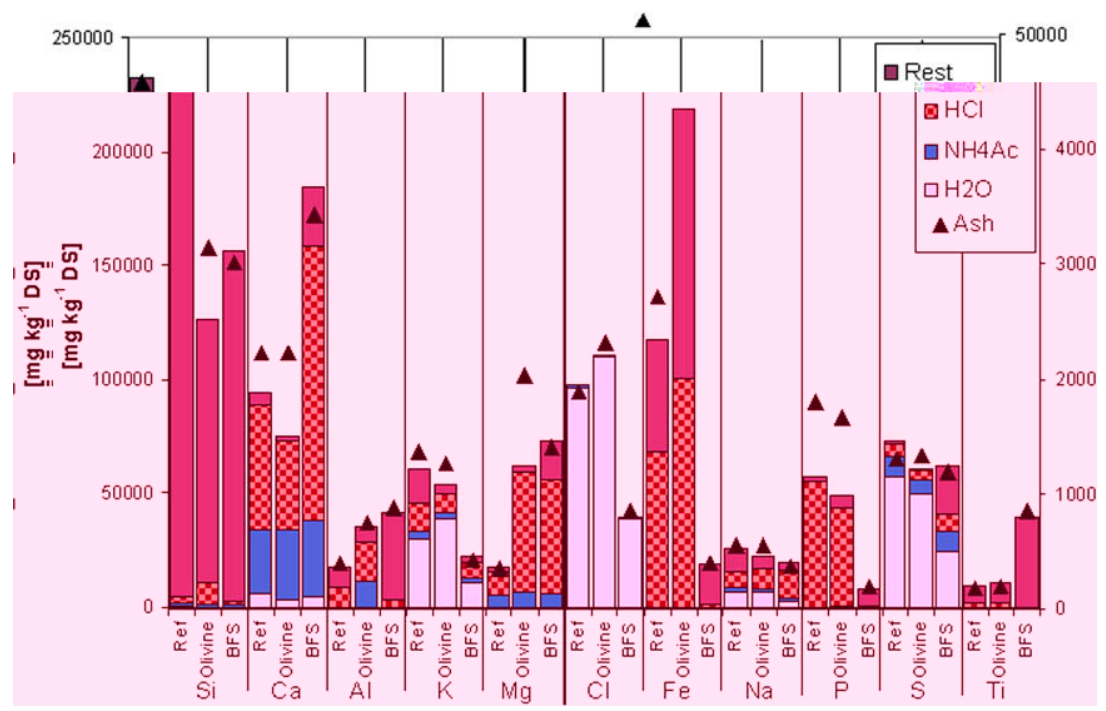

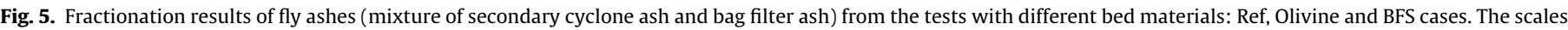
are different for half of the diagram (divided between $\mathrm{Mg}$ and $\mathrm{Cl}$ ). 
Ref case (0\%). The XRD results did not show any aluminium compounds that could explain this difference. Further studies are needed to show if this is a significant effect.
A comparison of the BFS case with the Ref case (Fig. 5) showed that the differences in the ash composition reflected the differences in the bed material compositions as well, see Table 2 . The

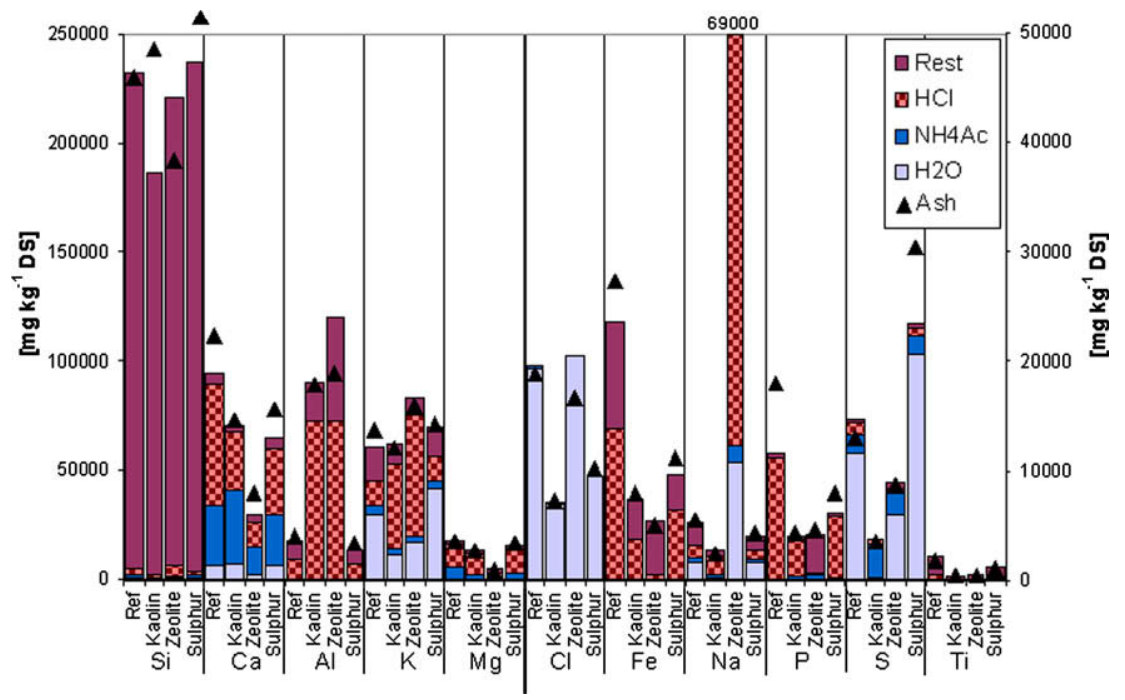

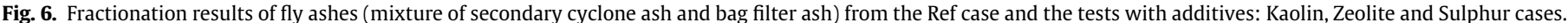
The scales are different for half of the diagram (divided between $\mathrm{Mg}$ and $\mathrm{Cl}$ ).

Table 9

Results of the spot analyses referring to Figs. 7-12 recalculated as oxides (wt\%).

\begin{tabular}{|c|c|c|c|c|c|c|c|c|c|c|c|c|c|c|c|c|c|c|c|c|c|}
\hline wt\% & $\mathrm{Na}_{2} \mathrm{O}$ & $\mathrm{MgO}$ & $\mathrm{Al}_{2} \mathrm{O}_{3}$ & $\mathrm{SiO}_{2}$ & $\mathrm{P}_{2} \mathrm{O}_{5}$ & $\mathrm{SO}_{3}$ & $\mathrm{Cl}$ & $\mathrm{K}_{2} \mathrm{O}$ & $\mathrm{CaO}$ & $\mathrm{Fe}_{2} \mathrm{O}_{3}$ & & $\mathrm{Na}_{2} \mathrm{O}$ & $\mathrm{MgO}$ & $\mathrm{Al}_{2} \mathrm{O}_{3}$ & $\mathrm{SiO}_{2}$ & $\mathrm{P}_{2} \mathrm{O}_{5}$ & $\mathrm{SO}_{3}$ & $\mathrm{Cl}$ & $\mathrm{K}_{2} \mathrm{O}$ & $\mathrm{CaO}$ & $\mathrm{Fe}_{2} \mathrm{O}_{3}$ \\
\hline \multicolumn{11}{|c|}{ Ref Sec. cyc } & \multicolumn{11}{|l|}{ Ref Bag } \\
\hline Spot 1 & 0 & 1 & 1 & 26 & 1 & 34 & 0 & 18 & 17 & 2 & Spot 1 & 1 & 7 & 1 & 45 & 5 & 5 & 1 & 5 & 29 & 1 \\
\hline Spot 2 & 8 & 0 & 9 & 76 & 0 & 0 & 1 & 6 & 1 & 0 & Spot 2 & 0 & 15 & 1 & 27 & 10 & 4 & 1 & 3 & 37 & 2 \\
\hline Spot 3 & 1 & 4 & 0 & 86 & 2 & 0 & 0 & 2 & 4 & 1 & Spot 3 & 1 & 26 & 1 & 14 & 11 & 7 & 3 & 9 & 28 & 1 \\
\hline Spot 4 & 0 & 0 & 0 & 44 & 0 & 57 & 0 & 7 & 9 & 0 & Spot 4 & 1 & 8 & 0 & 31 & 16 & 5 & 1 & 5 & 32 & 1 \\
\hline Spot 5 & 0 & 0 & 0 & 49 & 10 & 0 & 0 & 16 & 25 & 0 & Spot 5 & 0 & 4 & 0 & 8 & 2 & 23 & 2 & 3 & 58 & 1 \\
\hline Spot 6 & 0 & 1 & 0 & 15 & 1 & 48 & 1 & 21 & 19 & 3 & Spot 6 & 0 & 9 & 1 & 28 & 6 & 11 & 3 & 8 & 32 & 2 \\
\hline \multicolumn{11}{|c|}{ Olivin Sec. cyc } & \multicolumn{11}{|c|}{ Olivin Bag } \\
\hline Spot 1 & 0 & 1 & 9 & 74 & 0 & 0 & 0 & 14 & 1 & 0 & Spot 1 & 0 & 32 & 1 & 28 & 4 & 4 & 2 & 6 & 18 & 5 \\
\hline Spot 2 & 2 & 19 & 1 & 53 & 2 & 3 & 2 & 8 & 6 & 4 & Spot 2 & 0 & 6 & 0 & 5 & 1 & 5 & 32 & 43 & 6 & 1 \\
\hline Spot 3 & 0 & 1 & 74 & 12 & 1 & 1 & 0 & 1 & 7 & 1 & Spot 3 & 1 & 6 & 0 & 7 & 1 & 9 & 23 & 34 & 17 & 1 \\
\hline Spot 4 & 0 & 3 & 1 & 21 & 2 & 3 & 4 & 18 & 38 & 12 & Spot 4 & 0 & 11 & 3 & 27 & 3 & 9 & 8 & 19 & 18 & 3 \\
\hline Spot 5 & 0 & 2 & 2 & 13 & 0 & 0 & 1 & 20 & 51 & 12 & Spot 5 & 1 & 10 & 0 & 9 & 2 & 6 & 20 & 28 & 10 & 13 \\
\hline Spot 6 & 0 & 23 & 4 & 49 & 5 & 2 & 1 & 8 & 4 & 6 & Spot 6 & 0 & 7 & 13 & 46 & 1 & 4 & 6 & 12 & 9 & 1 \\
\hline \multicolumn{11}{|c|}{ BFS Sec. сус } & \multicolumn{11}{|c|}{ BFS Bag } \\
\hline Spot 1 & 0 & 16 & 5 & 40 & 0 & 6 & 0 & 1 & 33 & 0 & Spot 1 & 1 & 8 & 2 & 15 & 1 & 29 & 2 & 3 & 41 & 0 \\
\hline Spot 2 & 1 & 21 & 6 & 40 & 0 & 4 & 0 & 4 & 25 & 0 & Spot 2 & 0 & 15 & 2 & 13 & 0 & 26 & 2 & 2 & 39 & 1 \\
\hline Spot 3 & 0 & 7 & 2 & 11 & 0 & 0 & 0 & 3 & 76 & 0 & Spot 3 & 1 & 11 & 3 & 33 & 2 & 5 & 3 & 9 & 32 & 2 \\
\hline Spot 4 & 1 & 19 & 5 & 39 & 0 & 4 & 0 & 2 & 30 & 0 & Spot 4 & 0 & 8 & 2 & 16 & 1 & 30 & 2 & 4 & 37 & 0 \\
\hline Spot 5 & 1 & 13 & 7 & 50 & 0 & 2 & 1 & 5 & 20 & 1 & Spot 5 & 0 & 12 & 4 & 31 & 1 & 5 & 4 & 6 & 35 & 1 \\
\hline Spot 6 & 1 & 14 & 3 & 34 & 0 & 4 & 1 & 4 & 41 & 0 & Spot 6 & 0 & 10 & 2 & 17 & 1 & 4 & 19 & 26 & 21 & 0 \\
\hline \multicolumn{11}{|c|}{ Kaolin Sec. cyc } & \multicolumn{11}{|c|}{ Kaolin Bag } \\
\hline Spot 1 & 0 & 1 & 1 & 9 & 0 & 11 & 2 & 1 & 73 & 0 & Spot 1 & 1 & 34 & 3 & 37 & 3 & 1 & 0 & 4 & 15 & 3 \\
\hline Spot 2 & 1 & 0 & 20 & 59 & 0 & 0 & 1 & 18 & 0 & 1 & Spot 2 & 0 & 5 & 10 & 46 & 3 & 5 & 1 & 9 & 21 & 1 \\
\hline Spot 3 & 0 & 5 & 7 & 49 & 1 & 0 & 0 & 3 & 35 & 1 & Spot 3 & 0 & 5 & 10 & 50 & 2 & 2 & 1 & 10 & 18 & 1 \\
\hline Spot 4 & 0 & 1 & 5 & 26 & 0 & 31 & 0 & 38 & 7 & 0 & Spot 4 & 0 & 2 & 20 & 63 & 1 & 1 & 0 & 7 & 6 & 0 \\
\hline Spot 5 & 1 & 0 & 19 & 66 & 0 & 0 & 0 & 12 & 2 & 0 & Spot 5 & 1 & 1 & 9 & 69 & 0 & 0 & 0 & 16 & 3 & 0 \\
\hline Spot 6 & 0 & 1 & 13 & 61 & 1 & 0 & 0 & 16 & 7 & 1 & Spot 6 & 1 & 3 & 10 & 34 & 2 & 4 & 8 & 18 & 18 & 2 \\
\hline \multicolumn{11}{|c|}{ Zeolite Sec. cyc } & \multicolumn{11}{|c|}{ Zeolite Bag } \\
\hline Spot 1 & 13 & 3 & 4 & 39 & 1 & 11 & 6 & 15 & 6 & 2 & Spot 1 & 1 & 1 & 1 & 88 & 1 & 1 & 1 & 2 & 4 & 0 \\
\hline Spot 2 & 1 & 1 & 2 & 17 & 0 & 65 & 1 & 22 & 18 & 0 & Spot 2 & 4 & 0 & 21 & 66 & 1 & 1 & 1 & 4 & 3 & 0 \\
\hline Spot 3 & 1 & 8 & 5 & 38 & 13 & 1 & 0 & 6 & 22 & 8 & Spot 3 & 5 & 1 & 5 & 16 & 0 & 7 & 11 & 7 & 48 & 0 \\
\hline Spot 4 & 3 & 5 & 0 & 13 & 1 & 4 & 2 & 4 & 69 & 0 & Spot 4 & 6 & 0 & 20 & 59 & 1 & 1 & 1 & 9 & 3 & 0 \\
\hline Spot 5 & 3 & 2 & 4 & 43 & 1 & 23 & 1 & 12 & 15 & 0 & Spot 5 & 3 & 0 & 5 & 75 & 1 & 2 & 1 & 6 & 6 & 1 \\
\hline Spot 6 & 1 & 0 & 25 & 71 & 0 & 0 & 0 & 2 & 0 & 0 & & & & & & & & & & & \\
\hline \multicolumn{11}{|c|}{ Sulphur Sec. cyc } & \multicolumn{11}{|c|}{ Sulphur Bag } \\
\hline Spot 1 & 11 & 0 & 9 & 74 & 0 & 1 & 0 & 4 & 0 & 0 & Spot 1 & 1 & 2 & 0 & 7 & 1 & 10 & 1 & 9 & 4 & 63 \\
\hline Spot 2 & 1 & 4 & 1 & 59 & 4 & 3 & 2 & 8 & 17 & 1 & Spot 2 & 0 & 1 & 0 & 10 & 2 & 38 & 2 & 6 & 38 & 2 \\
\hline Spot 3 & 0 & 1 & 1 & 19 & 0 & 45 & 0 & 21 & 17 & 0 & Spot 3 & 2 & 5 & 2 & 22 & 2 & 23 & 4 & 19 & 19 & 1 \\
\hline Spot 4 & 1 & 2 & 0 & 79 & 2 & 2 & 2 & 7 & 6 & 0 & Spot 4 & 0 & 1 & 0 & 78 & 1 & 7 & 1 & 7 & 4 & 0 \\
\hline Spot 5 & 1 & 6 & 0 & 17 & 3 & 3 & 5 & 6 & 58 & 1 & Spot 5 & 1 & 4 & 0 & 17 & 5 & 16 & 11 & 29 & 16 & 1 \\
\hline Spot 6 & 0 & 1 & 11 & 62 & 1 & 5 & 1 & 13 & 6 & 2 & Spot 6 & 1 & 6 & 1 & 35 & 3 & 12 & 2 & 11 & 29 & 1 \\
\hline
\end{tabular}


slag contributes with $\mathrm{Ca}, \mathrm{Mg}$ and some $\mathrm{Al}$ but these are all mainly present in insoluble forms. In contrary to the Olivine case all the investigated elements, except $\mathrm{K}$, were harder bound in the ash in the BFS case compared with the Ref case. The concentration of $\mathrm{K}$ in the fly ash from the BFS case was less than half of those found in the Ref and Olivine cases and $40 \%$ of the $\mathrm{K}$ was hard bound according to the fractionation. However, the total amount of $\mathrm{K}$ in the boiler was much higher in the BFS case (Tables 4 and 5) due to the higher ash flows, especially the secondary cyclone ash flow was increased in this case, as discussed above. According to previous studies [1] a more stable fly ash (hard bound ash components) indicates fewer problems with deposits and bed agglomeration, thus promoting the BFS as bed material.

\subsection{Fractionations of fly ashes with different additives during combustion}

The fly ash composition of the Zeolite case was the one that differed most from the others and the Kaolin fly ash was rather similar (Fig. 6). The fly ash from the Kaolin and Zeolite cases had higher concentrations of $\mathrm{Al}$ compared to the Ref case and lower concentrations of Fe, Mg, P and S (Fig. 6). In both the Zeolite and Kaolin
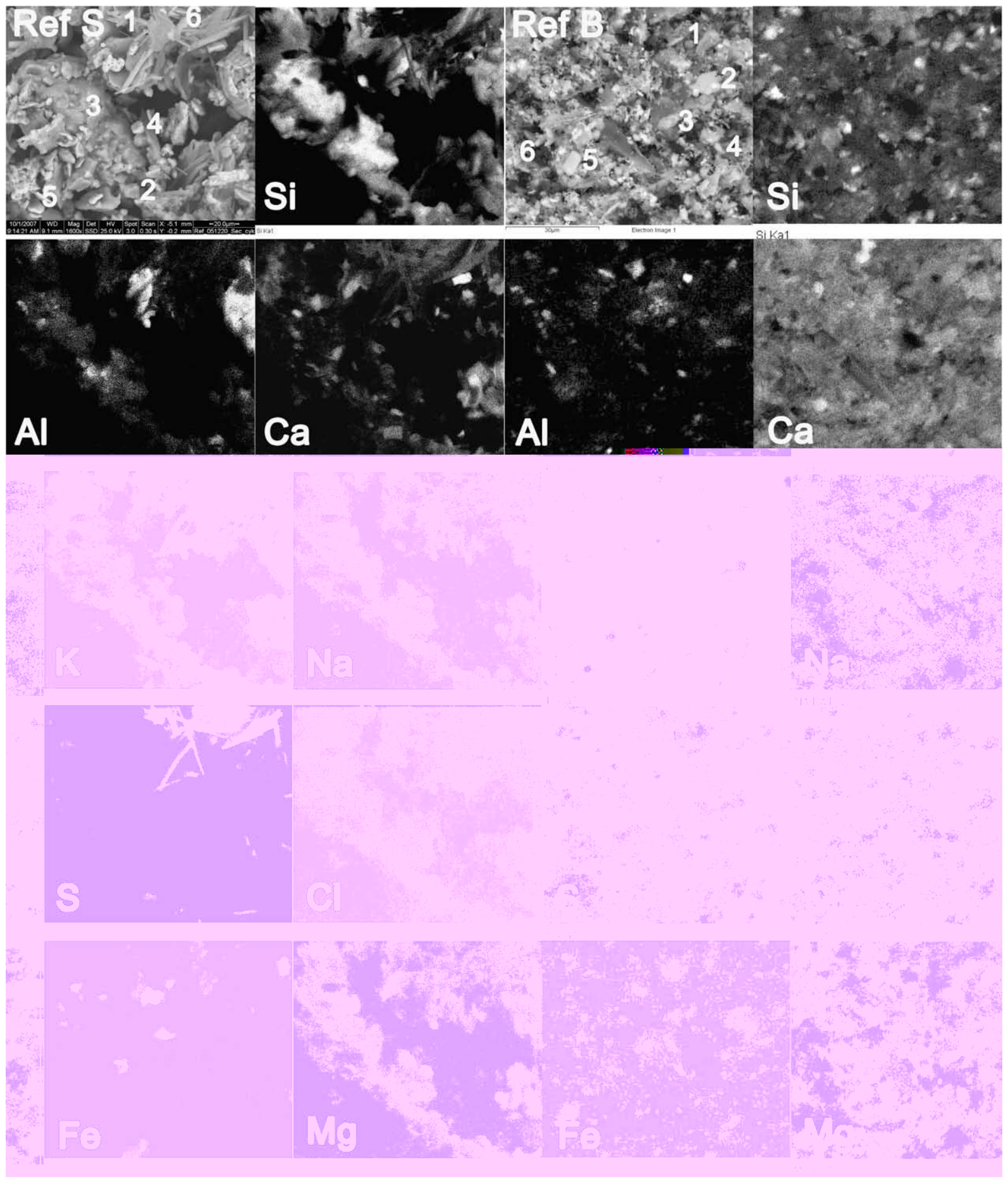

Fig. 7. SEM-EDX mapping of the Ref case, secondary cyclone (S) and bag filter ash (B). 
cases, $80 \%$ of the Na was hard bound in the fly ash compared to $65 \%$ in the Ref case. There were no differences in the solubility of $\mathrm{K}$ in the Kaolin and Zeolite cases were $75 \%$ was hard bound compared to $45 \%$ in the Ref case.

In the Sulphur case the sulphur concentration was somewhat higher than that of the other cases. Besides there were just marginal differences such as slightly lower concentrations of $\mathrm{Cl}, \mathrm{Al}$, $\mathrm{Ca}, \mathrm{Fe}, \mathrm{P}$ and $\mathrm{Ti}$, but with the same solubility. The concentrations of $\mathrm{Na}$ and $\mathrm{K}$ matched the Ref case but were slightly more soluble in the Sulphur case.

\subsection{SEM-EDX analysis}

The particle sizes of the secondary cyclone ash is in average between 5 and $100 \mu \mathrm{m}$ [21] and the particles in the bag filter ash are about $1 / 10$ th of the size of the secondary cyclone ash particles. The smaller particle size in bag filter ash makes it more difficult to get a good resolution with the EDX. However, the mapping pictures gave a relatively good comparison of the inherent variability in composition in the two fly ash fractions.

EDX analyses in points on the specimens mounted for SEM were also performed and the results are shown in Table 9. The locations of the spots are marked with Arabic numbers in the map picture of every ash sample. The precise point in the picture investigated as a spot is in the middle to the left of each number. The magnification of the secondary cyclone ashes is in the range of 1600-2900x and the size of the pictures are $100-200 \mu \mathrm{m}$ and the magnification of the bag filter ashes are in the range of 4500-6000x and the size of the pictures are $40-80 \mu \mathrm{m}$. All pictures contain size bars visible in a digital version.
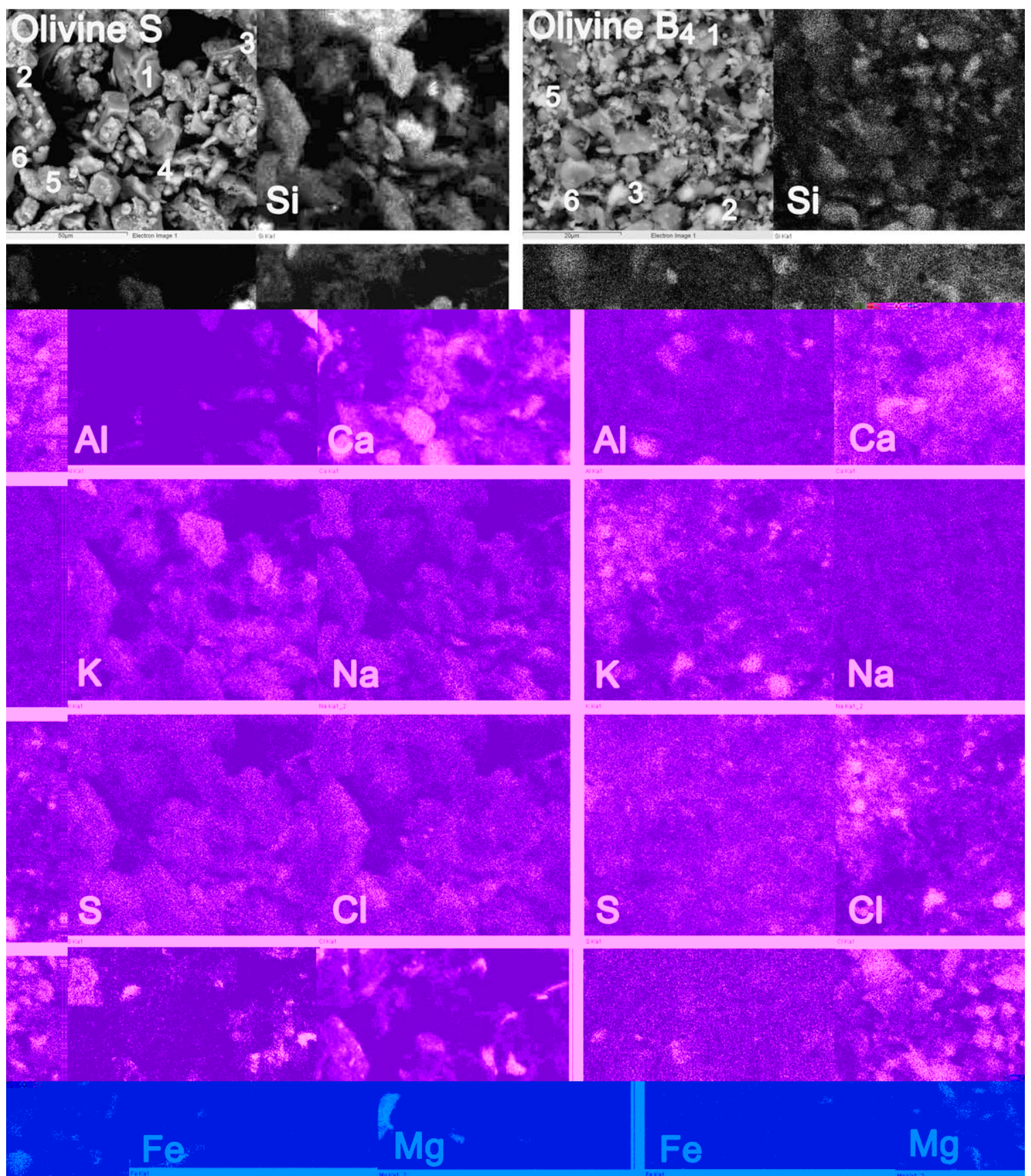

Fig. 8. SEM-EDX mapping of the Olivine case, secondary cyclone (S) and bag filter (B) ash. 
In the sec. cyclone ash from the Ref case (Fig. 7) K, S, Ca and Si (spot 1 and 6) was present in needle like crystals, but there was also a more diffuse structure containing both $\mathrm{K}$ and $\mathrm{Cl}$. The crystals are probably potassium sulphate or a potassium-calcium sulphate. The diffuse structure containing $\mathrm{K}$ and $\mathrm{Cl}$ may be $\mathrm{KCl}$ in small crystals. In the corresponding bag filter ash (Fig. 7) the elements were more evenly distributed over the sample which is natural since the particle size is smaller. However, the spot analysis results show some variability with, for example, two calcium sulphate particles (spot 5), two with mainly Mg, Si, Ca and P (spot 2 and 3) were spot 3 also contains $\mathrm{Na}, \mathrm{K}$ and $\mathrm{Cl}$, Fig. 7. The elemental maps of $\mathrm{K}, \mathrm{Na}, \mathrm{S}$, $\mathrm{Ca}$ and $\mathrm{Cl}$ correlated very well suggesting an even distribution of different sub-micron chloride and sulphate crystals. The mapping and spot results did in fact not show that the $\mathrm{Cl}$ concentration in this ash was much higher than in the sec. cyclone ash as the bulk results given in Table 4 did. This indicates that $\mathrm{Cl}$ is present as compounds as $\mathrm{HCl}$ and $\mathrm{KCl}$ condensed on the surface of the coarser ash particles in the ash, thus not found in any higher concentrations in the spot analysis.

In the Olivine secondary cyclone ash the $\mathrm{Cl}$ was evenly distributed over the particles as well as $\mathrm{S}, \mathrm{K}$ and $\mathrm{Na}$, Fig. 8. The Al distribution was very distinct and included one particle containing a large amount of $\mathrm{Al}$ corresponding to $74 \% \mathrm{Al}_{2} \mathrm{O}_{3}$ (spot 3 in Table 9 ). This high concentration in one particle unfortunately has the effect of reducing the intensity of the rest of the map. A couple of particles containing $\mathrm{K}, \mathrm{Al}$ and $\mathrm{Si}$ were found (spot 1) and spot 2 and 6 was dominated by $\mathrm{Mg}$ and $\mathrm{Si}$. Chlorine was found in combination with $\mathrm{K}, \mathrm{Ca}$ and $\mathrm{Fe}$ in spot 4 and 5 . In other parts of the sample big crystals (5-100 micron) was found consisting of $\mathrm{K}, \mathrm{Ca}$ and $\mathrm{S}$ indicating the presence of sulphates.
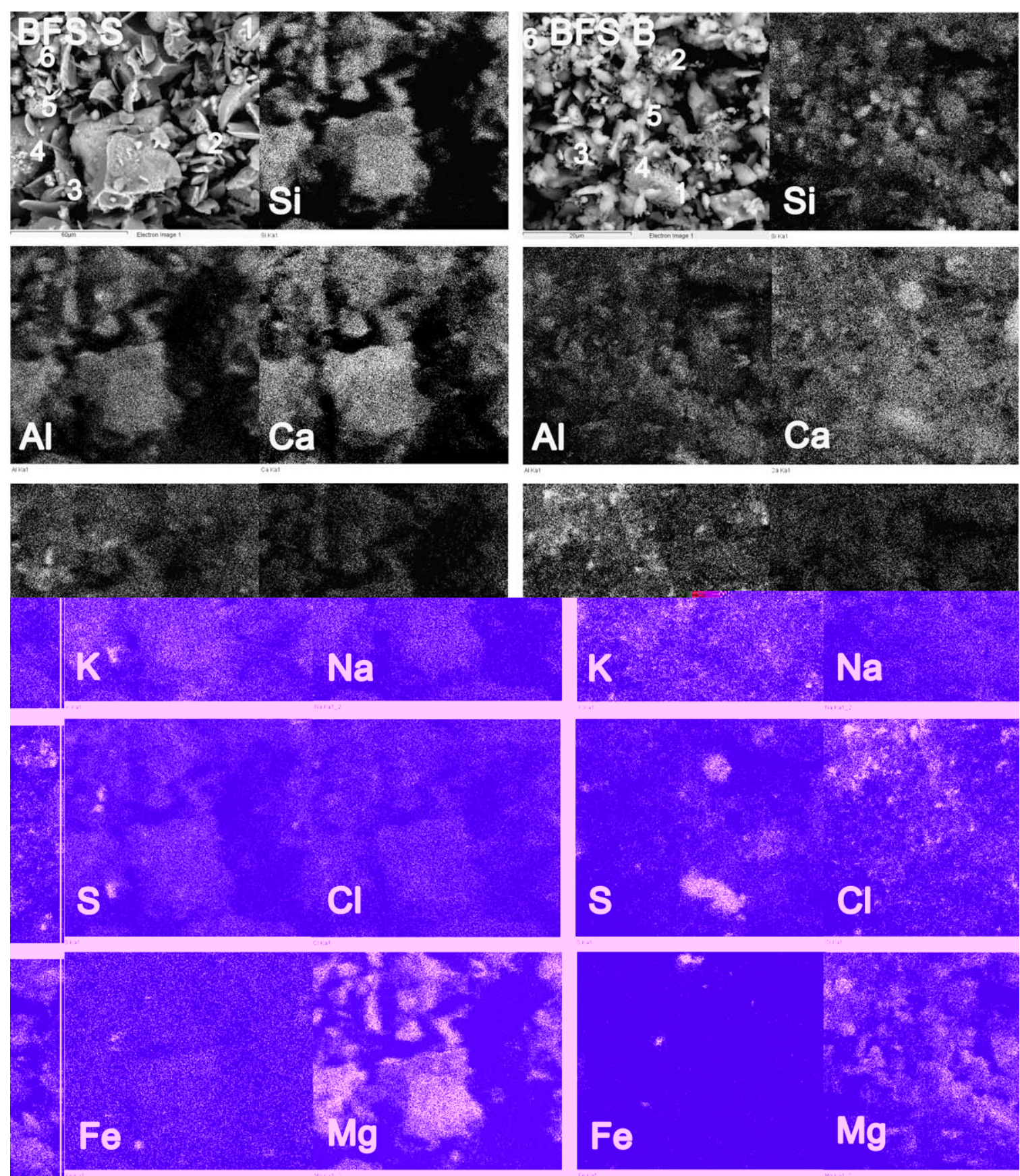

Fig. 9. SEM-EDX mapping of the BFS case, secondary cyclone and bag filter ash. 
The bag filter ash maps showed distributions of $\mathrm{K}$ and $\mathrm{Cl}$ that were almost identical and both were found in high concentrations, Fig. 8 and Table 9 . This ash was the only one containing super micron particles consisting of $\mathrm{KCl}$ (spot 2, Table 9). $\mathrm{Mg}$ correlated mainly with $\mathrm{K}$ and $\mathrm{Ca}$ and the elements $\mathrm{S}$ and Na were more evenly distributed over the sample. Both the sec. cyclone ash and bag filter ash from the olivine case seemed a little coarser than the ashes from the Ref case.

The secondary cyclone ash from the test with BFS as bed material had many similarities to the secondary cyclone ash from the olivine case (Fig. 9). There were some correlations between $\mathrm{K}$ and $S$ found, otherwise the elements was evenly distributed over the sample. The particles in this ash mainly consisted of Ca and Si together with $\mathrm{Al}$ and $\mathrm{Mg}$, see Tables 4 and 9.

In the bag filter ash from the BFS case the $\mathrm{K}$ and $\mathrm{Cl}$ matched very well (Fig. 9 and spot 6) in addition to $\mathrm{Ca}$ and $\mathrm{S}$ (spots 1,2 and 4) proposing the presence of $\mathrm{KCl}$ and $\mathrm{CaSO}_{4}$. No correlations between $\mathrm{K}, \mathrm{Na}$ and $\mathrm{S}$ were seen on the element maps. The BFS is the only bed material containing Ca, Table 2 . This calcium may capture sulphur and suppress the sulphation of potassium if released during combustion [22].

The BFS fly ashes had the lowest concentration of alkali of all the investigated ashes and the chlorine concentration was low as well. This is a result of the original fine fraction of the bed material together with bed material attrition giving a significant addition of small particles to the fly ashes. The entrained bed material had to be replaced with fresh slag and thus, the ash flows became much diluted. In addition this case had the lowest $\mathrm{KCl}$ and $\mathrm{HCl}$ concentrations in the flue gas among the cases with different bed materials as discussed above.

Kaolin addition gives relatively high $\mathrm{Al}$ and $\mathrm{Si}$ concentrations in the fly ashes, Table 4. The EDX element maps from the secondary cyclone ash showed clear correlations between the distributions of $\mathrm{Si}, \mathrm{Al}$ and $\mathrm{K}$ (Fig. 10) and spot 2, 5 and 6 (Table 9). In addition, a number of small particles with compositions indicating $\mathrm{K}_{2} \mathrm{SO}_{4}$, $\mathrm{CaSO}_{4}$ and $\mathrm{KCl}$ were found.

The distribution of $\mathrm{Si}$ and $\mathrm{Al}$ in the bag filter ash particles to some extent agreed with that of potassium. However, potassium was also found in combination with $\mathrm{Cl}$, Ca and S (Fig. 10). This was supported by the spot analysis (Table 9, spot 2, 3 and 6) were $\mathrm{K}$ was found with $\mathrm{Ca}, \mathrm{Si}, \mathrm{Al}, \mathrm{Cl}$ and $\mathrm{S}$. This shows that the potassium speciation included aluminium silicate as well as sulphate and chloride.

The Zeolite case fly ash showed similar element distributions as the Kaolin case (Fig. 6). The main differences were the higher $\mathrm{Cl}, \mathrm{Al}$ and $\mathrm{Na}$ concentrations in the fly ash of the Zeolite case and the lower $\mathrm{Ca}$ concentration, Fig. 6. The secondary cyclone ash contained similar needle like crystals with $\mathrm{K}, \mathrm{Ca}$ and $\mathrm{S}$ as found in the Olivine case in addition to spherical particles containing $\mathrm{Ca}$, $\mathrm{Si}, \mathrm{Al}$ and $\mathrm{Mg}$. Also calcium phosphate and potassium sulphate

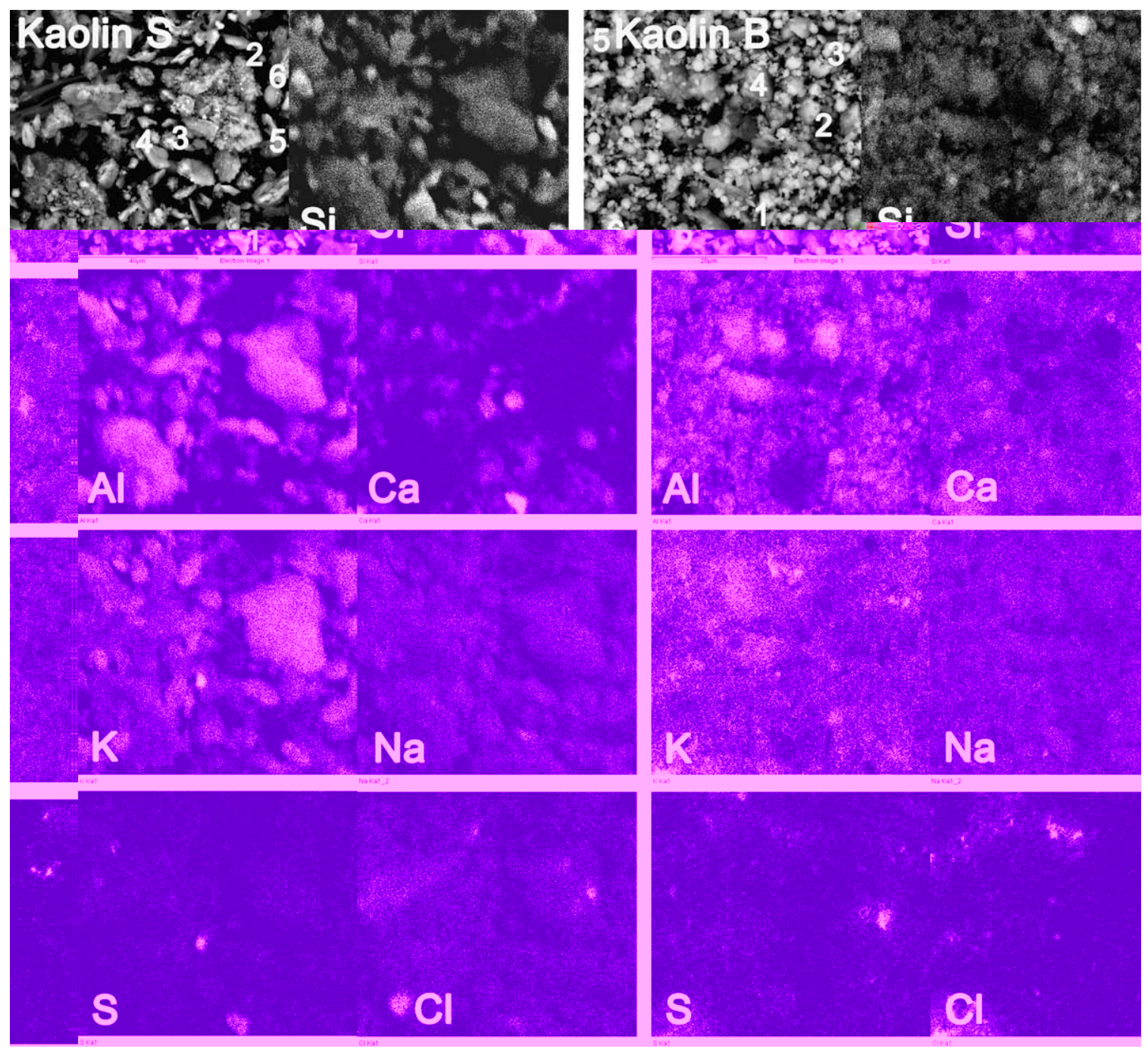

Fig. 10. SEM-EDX mapping of the Kaolin case, secondary cyclone and bag filter ash. 


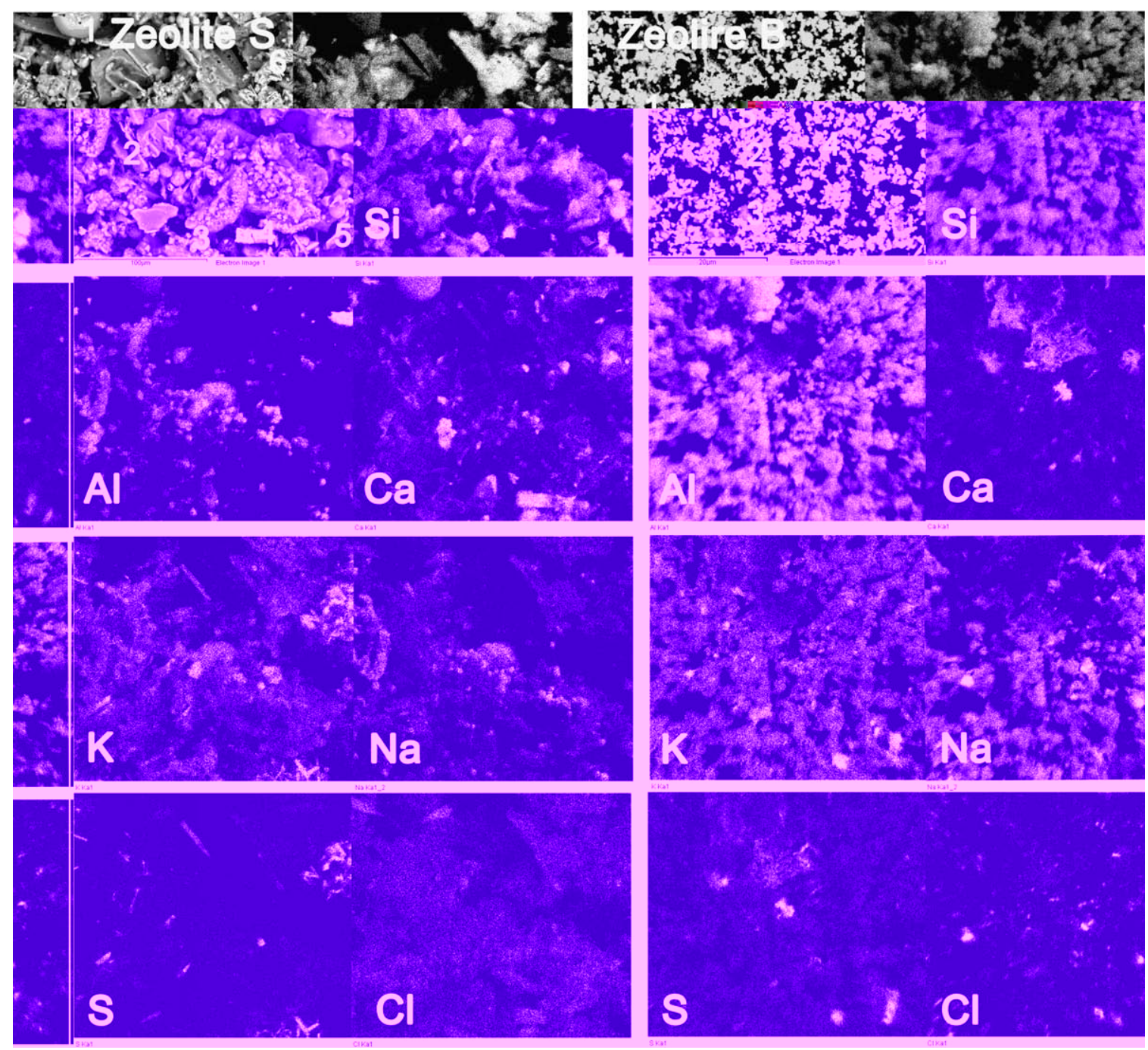

Fig. 11. SEM-EDX mapping of the Zeolite case, secondary cyclone (S) and bag filter (B) ash.

was found as well as a correlation between the distributions of $\mathrm{Na}$, $\mathrm{K}$ and $\mathrm{Al}$, Fig. 11 . In the spot analysis particles containing mainly $\mathrm{Na}, \mathrm{K}, \mathrm{Si}, \mathrm{S}$ and $\mathrm{Cl}$ were found (spot 1 ) and $\mathrm{Na}, \mathrm{K}, \mathrm{Al}$ and $\mathrm{Si}$ (spot 6 ) indicating a $\mathrm{K}$ uptake by the added zeolites. Some spots containing $\mathrm{K}, \mathrm{S}, \mathrm{Ca}$ and $\mathrm{Si}$ were also found (spot 2 and 5 ). The XRD results did not show any detectable amount of potassium chloride or sulphate but this can be due to the small crystallite size of these compounds. Very small crystallites do not contain a large enough number of crystals oriented in a random manner in order to give a visible powder diffraction pattern. This effect is generally referred to as the compounds being "X-ray amorphous".

The bag filter ash contained a lot of zeolite particles entrained with the flue gas from the combustion chamber. This is an effect of the low density and small particle size of the zeolites in combination with a high fluidization velocity in the combustion chamber $(5 \mathrm{~m} / \mathrm{s})$. The EDX results for this ash showed clear correlations between $\mathrm{Si}, \mathrm{Al}, \mathrm{K}$ and $\mathrm{Na}$ and also between $\mathrm{Ca}$ and $\mathrm{S}$, see Fig. 11. In addition, some small $\mathrm{NaCl}$ particles were found. The spot analyses showed generally high Si concentrations and varying concentrations of $\mathrm{Al}, \mathrm{Ca}$ and alkali (Table 9). This ash had the highest alkali and $\mathrm{Cl}$ content among the investigated ashes, Table 4 .

The SEM-EDX results for secondary cyclone ash from the test with sulphur addition showed needle like crystals containing $\mathrm{K}$, $\mathrm{Ca}$ and S (spot 3 in Fig. 12). They seemed to contain Si as well but this may be a response from other ash particles under the crystals. The electron beam affects a sample volume of about $1 \mu \mathrm{m}$ in diameter. The spot analyses showed co-occurrence of $\mathrm{Na}, \mathrm{Si}, \mathrm{S}, \mathrm{Cl}$ and $\mathrm{K}$ (spot 1 ) and $\mathrm{K}, \mathrm{Si}$ and $\mathrm{Al}$ (spot 6).These findings were supported by the XRD results showing potassium in the forms $\mathrm{KCl}$, $\mathrm{K}_{2} \mathrm{SO}_{4}$ and as $\mathrm{K}$-aluminium-silicate (Table 8 ).

The bag filter ash element distributions showed correlations between $\mathrm{K}, \mathrm{Ca}$ and $\mathrm{S}, \mathrm{K}$ and $\mathrm{Cl}$ as well as $\mathrm{Na}$ and $\mathrm{Al}$. The spot analyses showed $\mathrm{K}$ and $\mathrm{S}$ together with $\mathrm{Ca}, \mathrm{Cl}$ and $\mathrm{Si}$, see Table 9.

\section{Discussion and conclusions}

Exchange of the normal silica sand bed material for olivine sand or BFS changed the chemical composition of the fly ash fractions due to entrainment of small bed material particles. In the BFS case, the attrition of the bed material was significant and this forced an unusually large bed material replacement and unusually large ash flows. Probably the amorphous slag is more brittle than the crystalline quartz and olivine sand types. Another slag treatment process giving a larger crystalline fraction may give a material that could better withstand the attrition in the fuel bed. The addition of kaolin and zeolite also added extra material to the fly ash flow and changed the fly ash composition in the direction of higher aluminium and silicon contents. Both these solid additives have small average 


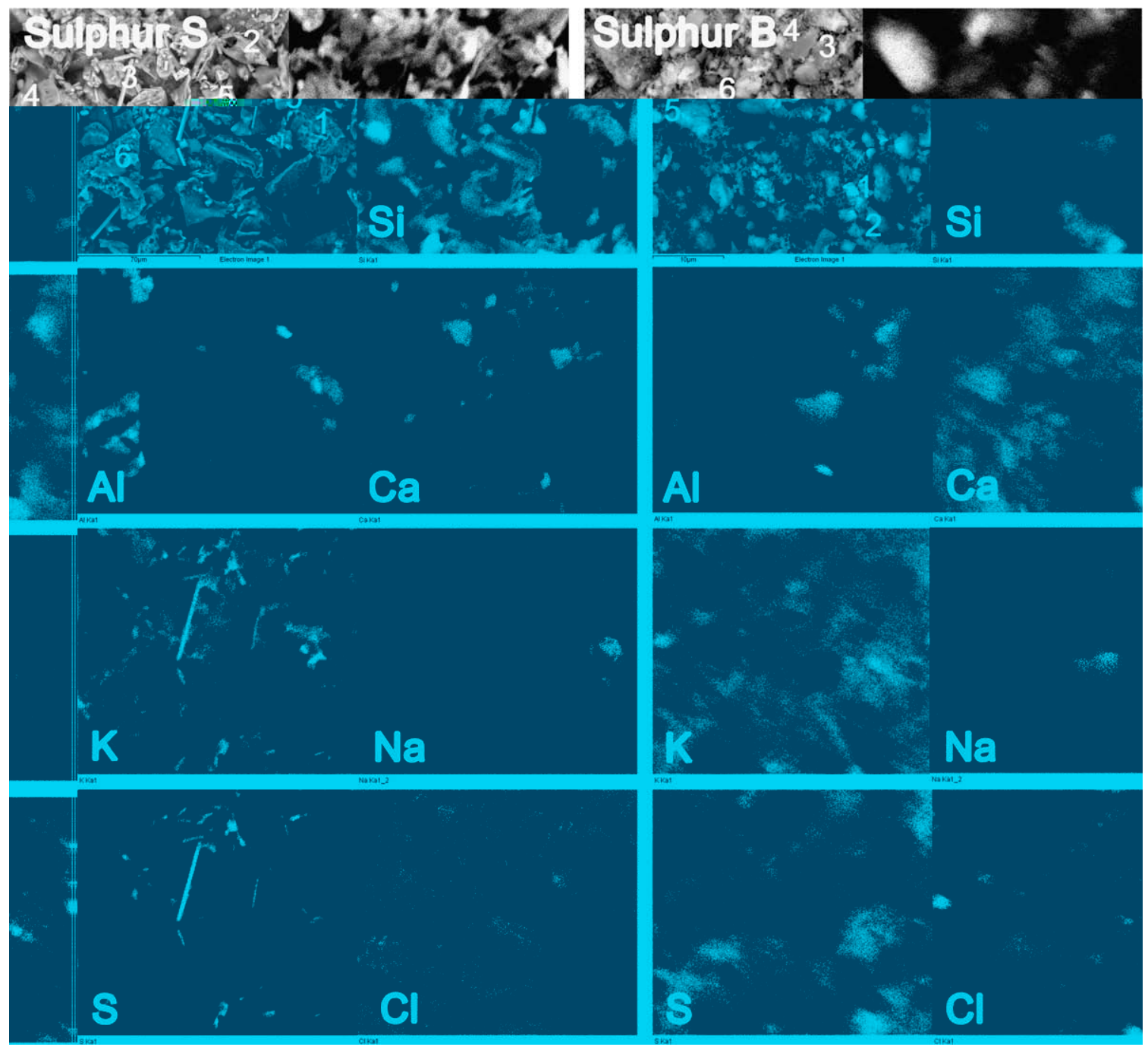

Fig. 12. SEM-EDX mapping of the Sulphur case, secondary cyclone and bag filter ash.

particle size and are rather easily entrained with the flue gas. This has to be taken into account when designing the additive inlet system and choosing a suitable inlet point in order to maximise the additive-gas contact time.

An important reason for choosing an alternative bed material or using an additive is that the flue gas content of vaporous $\mathrm{KCl}$ needs to be decreased in order to minimise the risk for ash deposition and corrosion on super heater tubes. Another, also important, reason is to avoid bed material agglomeration due to formation of sticky surface layers of ash compounds on the bed material particles. A surface layer of fuel ash components was formed on olivine sand particles as well as on quartz particles. However, the composition of the layer on olivine was different from that on quartz being rich in calcium but not in potassium as is common for quarts particles. The potassium components from the ash were concentrated to silicate particles in the bed material also in the olivine test. When potassium rich ash melts lumps were attached to bed material particles, the ash layer closest to the bed sand surface was calcium rich [19]. A very limited formation of ash component layers was found on BFS bed material particles. The layers formed contained $\mathrm{K}, \mathrm{Si}$ and $\mathrm{Ca}$ and they occurred as local spots on the particles surfaces. Thus, in this case, as in the olivine case, the potassium compounds in the fuel ash do not react with the bed sand but stays in more or less melted ash lumps [19].
The results obtained in this work showed that the Olivine sand gave the highest $\mathrm{KCl}$ concentrations in the flue gas before the convection section, i.e. twice as high as the Ref case with Silica sand. All the other measures against ash deposit formation tested here had a smaller, but significant, suppressing influence on the level of $\mathrm{KCl}$ in the flue gas and in most cases the $\mathrm{HCl}$ level increased at the same time.

In all cases the main part of the $\mathrm{Cl}$ was found in the flue gas apart from the Olivine case were most $\mathrm{Cl}$ was found in the bag filter ash flow. The SEM-EDX analysis and XRD showed that the $\mathrm{K}$ was generally associated with $\mathrm{Cl}$ with addition of some potassium aluminium-silicates in the fly ash in the cases with alternative bed materials. The chemical fractionation showed that the alkali in the fly ash from the BFS case was slightly less soluble than the cases with Silica sand and Olivine sand. This indicates that BFS reduces the combustion problems in comparison with the other two bed materials. However, other investigations have found an increased deposit formation rate using BFS as bed material compared to silica sand. When olivine sand was used, soluble forms of potassium were more abundant than insoluble ones. The additives kaolin, zeolites and sulphur gave almost the same distribution of potassium between bed material, secondary cyclone ash and filter ash. In the zeolite case, the outflow of potassium was smaller than the inflow which indicates formation of deposits in the boiler. The 
same effect was observed for $\mathrm{Na}$, Ca and Al zeolite related elements. In addition, the filter ash was enriched in $\mathrm{K}, \mathrm{Na}, \mathrm{Si}$ and $\mathrm{Al}$ as compared to the ash from the Reference case. Similarly, the filter ash formed in the Kaolin case was enriched in K, Si and Al. The fractionation results showed no significant difference in the solubility of alkali metals between the Kaolin and Zeolite fly ashes and both had the largest fraction of hard bound alkali among all the cases which indicates a capture of alkali as alkali-aluminium silicates. Both SEM-EDX and XRD confirmed the presence of non-soluble alkali-aluminium-silicates and this indicates that there is a capture of potassium in aluminium-silicates in the combustion chamber.

The addition of sulphur is done with the aim to transform potassium from chloride to sulphate, thus decreasing its corrosion effect in ash deposits on super heater tubes [23]. It was observed that $93 \%$ of the sulphur and $87 \%$ of the chlorine coming into the boiler was present in gaseous form in the convection part. The fly ash also had a high concentration of sulphur and $95 \%$ of it was soluble. The main part of the potassium was found in the bed ash but $39 \%$ reached the fly ash fraction of which $65 \%$ was soluble. This supports the assumption that most alkali in these fly ashes is bound as soluble $\mathrm{K}_{2} \mathrm{SO}_{4}$ in addition to some remaining $\mathrm{KCl}$ which also was confirmed by the XRD. The insoluble part is probably bound as $\mathrm{KAISi}_{3} \mathrm{O}_{8}$, thus captured by aluminium-silicate.

In the Reference case much alkali is captured in the bed causing agglomeration. In addition the concentration of $\mathrm{KCl}$ is the gas phase is high. Gaseous $\mathrm{KCl}$ deposits on the heat transfer surfaces and causes corrosion. Most of the alkali found in the fly ash fraction was reactive.

Olivine as bed material did not decrease the alkali problems in the combustion on the contrary the $\mathrm{KCl}$ concentrations before the convection pass increased to the double. In addition the alkali in the fly ash fraction was even more reactive than in the Ref case. The only positive effect was a slightly decreased alkali capture in the bed material.

BFS decreased the alkali problems to some extent. $\mathrm{KCl}$ before the convection pass decreased with $20 \%$ and the alkali captured in the bed was slightly decreased.

Kaolin decreased $\mathrm{KCl}$ and increased $\mathrm{HCl}$ before the convection pass. Most alkali was found in the fly ash fractions and predominantly in stable forms. The $\mathrm{Cl}$ was found in the bag filter ash and in the flue gas.

Zeolite addition resembled to the Kaolin addition with decreased $\mathrm{KCl}$ and increased $\mathrm{HCl}$ before the convection pass. About $80 \mathrm{wt} \%$ of the alkali was found in the bag filter ash and predominantly in stable forms.

Sulphur decreased both $\mathrm{KCl}$ and $\mathrm{HCl}$ before the convection pass and $\mathrm{SO}_{2}$ increased to over ten times the concentrations in the reference case. Much alkali was captured in the bed ash and $70 \%$ of the alkali found in the fly ash fraction was reactive.

\section{Acknowledgments}

Main support for this work was provided by the Swedish Energy Administration. The large scale tests were partly performed as part of Contract No. A5-509 from VärmeForsk Service AB which is gratefully acknowledged. Vattenfall Power Consultant supplied the IACM instrument and Ångpanneföreningen contributed with fundings for additional analyses. Further, the authors acknowledge Akademiska Hus AB for maintaining and operating the boiler and the research staff employed by Chalmers University of Technology for carrying out the combustion tests.

\section{References}

[1] Pettersson A, Zevenhoven M, Steenari B-M, Åmand L-E. Application of chemical fractionation methods for characterisation of biofuels, waste derived fuels and CFB co-combustion fly ashes. Fuel 2008;87:3183-93.

[2] Åmand L-E, Leckner B, Eskilsson D, Tullin C. Deposit on heat transfer tubes during co-combustion of biofuels and sewage sludge. Fuel 2006;85:1313-22.

[3] Benson SA, Holm PL. Comparison of inorganic constituents in three low-rank coals. Ind Eng Chem Prod Res Dev 1985;24:145-9.

[4] Baxter LL, Miles T, Miles Jr T, Jenkins B, Milne T, Dayton D, et al. The behaviour of inorganic material in biomass-fired power boilers: field and laboratory experiments. Fuel Process Technol 1998;54:47-78.

[5] Zevenhoven-Onderwater M. Ash-forming matter in biomass fuels. Finland: $\mathrm{PhD}$ thesis, Department of Chemical Engineering, Åbo Akademi University; 2001 [ISSN: 1457-7895, ISBN: 952-12-0813-9].

[6] Lin W, Dam-Johansen K, Frandsen F. Agglomeration in bio-fuel fired fluidized bed combustors. Chem Eng J 2002;96(1-3):171-85.

[7] Öhman M, Nordin A. Bed agglomeration characteristics duration fluidized bed combustion of biomass fuels. Energ Fuel 2000;14:169-78.

[8] Brus E, Öhman M, Nordin A, Boström D, Hedman H, Eklund A. Bed agglomeration characteristics of biomass fuels using blast-furnace slag as bed material. Energ Fuel 2004;18:1187-93.

[9] Tran K-Q, Iisa K, Steenari B-M, Lindqvist O. A kinetic study of gaseous alkali capture by kaolin in the fixed bed reactor equipped with an alkali detector. Fuel 2005;84:169-75.

[10] Tran K-Q, Iisa K, Hagström M, Steenari B-M, Lindqvist O, Pettersson JBC. On the application of surface ionization detector for the study of alkali capture by kaolin in a fixed bed reactor. Fuel 2004;83:807-12.

[11] Breck DW, Eversole WG, Milton RM, Reed TB, Thomas TL. Crystalline zeolites. I. The properties of a new synthetic zeolite, type A. J Am Chem Soc 1956;78(23):5963-72.

[12] Broström M, Kassman H, Helgesson A, Berg M, Andersson C, Backman R, et al. Sulfation of corrosive alkali chlorides by ammonium sulfate in biomass fired CFB boiler. Fuel Process Technol 2007;88(11-12):1171-7.

[13] Hindiyarti L, Frandsen F, Livbjerg H, Glarborg P, Marshall P. An exploratory study of alkali sulfate aerosol formation during biomass combustion. Fuel 2008;87:1591-600.

[14] Kassman H, Andersson C, Höglund J, Åmand L-E, Davidsson K. Gas phase alkali chlorides and deposits during co-combustion of coal and biomass. In: Proc of the 19th internat conf on fluidized bed combustion, Vienna, Austria; May 2006.

[15] Valmari T, Lind TM, Kauppinen EI, Sfiris G, Nilsson K, Maenhaut W. Field study on ash behavior during circulating fluidized-bed combustion of biomass. 1 . Ash formation. Energ Fuel 1999;13:379-89.

[16] Valmari T, Lind TM, Kauppinen EI, Sfiris G, Nilsson K, Maenhaut W. Field study on ash behavior during circulating fluidized-bed combustion of biomass. 2 . Ash deposition and alkali vapour condensation. Energ Fuel 1999;13:390-5.

[17] Johansson L, Leckner B, Tullin C, Åmand L-E, Davidsson K. Properties of particles in the fly ash of a biofuel fired CFB-boiler. Energ Fuel 2008;22(5):3005-15.

[18] PDF-4. International Centre for Diffraction Data (ICDD), Newtown Square Pennsylvania, USA; 2008. Available from: http://www.icdd.com.

[19] Davidsson KO, Åmand L-E, Steenari B-M, Elled A-L, Eskilsson D, Leckner B. Countermeasures against alkali-related problems during combustion of 2008;22(5):3005(62w)-956):3005-15. 